This article is distributed under the terms of the Creative Commons Attribution 3.0 PL (c) Copyright by Uniwersytet Warszawski Katedra Studiów Interkulturowych Europy Środkowo-Wschodniej \& individual articles to their Authors

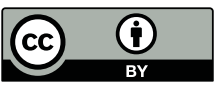

doi: 10.32612/uw.2543618X.2019.pp.117-158

Przegląd Środkowo-Wschodni, 4, 2019

ISSN 2543-618X elSSN 2545-1324

Nr art. 20190407

Data przesłania: 15.03 .2018

Аляксандр Пагарэлы

Data akceptacji: 23.05.2018

Instytut Slawistyki Polskiej Akademii Nauk

mbv.mancunian@gmail.com

ORCiD: 0000-0003-2182-6656

\title{
Праблема дысцыпліны часу ў дыскурсе друку БХД-БНА міжваеннага перыяду
}

\section{Problem dyscypliny czasu w dyskursie druku BChD-BZL w okresie międzywojennym}

Artykuł jest próbą zbadania problematyki dyscypliny czasu w dyskursie prasy międzywojennej Białoruskiej Chrześcijańskiej Demokracji. Ten dyskurs był ważnym elementem w budowaniu wizji moralnej wspólnoty politycznie, społecznie i gospodarczo aktywnych Białorusinów. Jednak tło społeczno-kulturowe, a nie tylko czynniki natury politycznej w znacznym stopniu wpływały na to, że ten dyskurs miał ograniczony wpływ na wieś białoruską. Artykuł proponuje typologię czasu społecznego, która cechuje postawy wobec czasu BChD oraz innych ruchów politycznych Białorusi Zachodniej.

Słowa kluczowe: czas społeczny, prasa, Zachodnia Białoruś, okres międzywojenny, Białoruska Chrześcijańska Demokracja

Англічанін, кажуцьь, пакуль возьмецица да работь насамперш падумае, патом парадзіцица, а патом ужо робіць; Немец падумае моцна спачатку $і$ зараз бярэциа за работу, а наш Беларус падумае крыху, пачухаециц, пералічыць перашкоды і на печ палезе.

Газета „Biełarus”, 1913 г.

Хто разважае пра будучыню, той круцель: важная толькі сучаснасиь.

Луі Фердынанд Сэлін, «Падарожжа на край ночы», 1932 г. 


\section{Уступ}

Перыяды бурлівых палітычных, сацыяльных і культурных перамен вызначаюцца дэзарыентацыяй, бо папярэднія катэгорыі, якія дазвалялі б успрымаць рэчаіснасць і сувязі паміж яе элементамі як упарадкаваныя, перастаюць дзейнічаць. Сітуацыі, якія называюць «пераходным перыядам», цяжка ўкладваюцца уу звыклыя тлумачальныя схемы, і розныя сацыяльныя і палітычныя актары, што маюць інтарэсы і шансы прайграць або выйграць (з іх перспектывы), могуць палярна альбо нейтральна ацэньваць такія сітуацыі і мець свае погляды на канцавы вынік такіх перыядаў. Такі часовы адрэзак можна назваць «часам цудаў», калі могуць здарацца рэчы, якія супярэчаць папярэднім правілам і традыцыям. Гэта лімінальныя сітуацы ${ }^{1}$.

Ваенна-рэвалюцыйная віхура, што пранеслася па беларускіх землях у 1914-1921 гадах (канцавую дату можна паставіць і пазнейшую), можа быць аднесена якраз да такіх «пераходных перыядаў», якія адкрываюць магчымасці і перспектывы 3 пункту гледжання адных актараў або, наадварот, закрываюць, з пункту гледжання іншых. Для вызначэння такога становішча, калі ўсё грамадства ці пэўная яго частка папярэдне не гатова да прыняцця новых для сябе роляў і ідэнтычнасцей, вымушана гэта рабіць пад ціскам знешніх акалічнасцей, перуанскі гісторык Нельсан Манрыке назваў «паскарэннем гістарычнага часу» ${ }^{2}$.

Перад грамадствам могуць стаяць альтэрнатывы і раздарожжы, якія пры пэўных умовах могуць стаць шансамі для пашырэння яго магчымасцей, павелічэння рэсурсаў, узмацнення пазіцый. Але сітуацыя пераходу можа пакінуць след не меншы, чым увесь папярэдні вопыт гэтага грамадства.

${ }^{1}$ А. ван Геннеп, Обряды перехода, Москва 2002; V. Turner, Drams, Fields and Metaphors. Symbolic Action in Human Society, Ithaca, London 1974, p. 231-271.

${ }^{2}$ F. E. Mallon, Peasant and Nation. The Making of Postcolonial Mexico and Peru, Berkeley, Los Angeles, London 1995, p. 2. 
Менавіта 3 такімі выклікамі сутыкнулася палітычная арганізацыя, якая была адным 3 самых значных палітычных актараў, а ў пэўныя перыяды прадстаўляла інтарэсы беларускага грамадства ў Польшчы ў цэлым - Беларуская хрысціянская дэмакратыя (БХД) (пазней Беларускае народнае аб'яднанне (БНА)). Гэта ўвасобілася ў дыскурсе выданняў гэтай партыі (групоўкі, якія адгалінаваліся ад яе ў канцы 1930-х гадоў, інакш канцэптуалізавалі свае светапогляды $)^{3}$, якая пачала разглядаць вектар развіцця заходнебеларускага грамадства (калі не ўсяго беларускага грамадства ў цэлым) як эвалюцыйны, скіраваны ў будучыню, звязаны $з$ прагрэсам. Час атрымаў маральнае вымярэнне, стаў разглядацца як рэсурс і быў падпарадкаваны канцэпцыі эвалюцы ${ }^{4}$, на якую глядзелі як на шлях да сацыяльнай трансфармацыі. 3 гэтага вынікала неабходнасць правільна распараджацца часам, патрабавалася адказнае і дысцыплінаванае стаўленне да яго. Як разуменне часу ўвасаблялася ў дыскурсе друку БХД, а таксама фактары, што абумовілі такое яго разуменне, мы будзем разглядаць у гэтым артыкуле.

Канцэпцыя дысцыпліны часу паводле БХД не адлюстравана ў яе палітычных праграмах. Хоць праграмныя дакументы нельга цалкам ігнараваць, але яны ўяўляць толькі частку масіву матэрыялу неабходнага для разумення праблематыкі. Паводле Фларэнсіі Малон, дыскурс з' яўляецца адкрытым працэсам у рамках культурнага, палітычнага і ідэалагічнага ўзаемадзеяння 5 . Гэта не азначае аднак, што гэта працэс, які не мае пэўных канкрэтных вынікаў, і разглядаць яго трэба толькі ў рамках міжваеннага перыяду, які скончыўся выбухам Другой сусветнай вайны. Гэта азначае, што трэба прыцягнуць большае кола матэрыялаў, якія дазволяць атрымаць больш

${ }^{3}$ M. Moroz, ,Krynica”. Ideologia i przywódcy biatoruskiego katolicyzmu, Białystok 2001.

${ }^{4}$ A-č, Duch času i biełarusy, „Krynica” 1918, № 2, 14 studnia, s. 1; А. Вашкевіч, Эвалючьыя Беларускай Хрысиіянскай Дэмакратыі у святле яе палітычных праграм [у:] «Спадчына» 2006, № 1, с. 30, 32.

${ }^{5}$ F. E. Mallon, op. cit., p. 90. 
разнастайную карціну таго, што ўяўляў з сябе дыскурс друку БХД (перш за ўсё газета «Крыніца», а ў 1925-1937 гадах «Беларуская крыніца», часопісы «Хрысьціянская думка», «Шлях моладзі», «Самапомач», «Беларускі фронт») па праблеме часу.

Апрача самой прэсы, некаторых архіўных матэрыялаў, зборнікаў публіцыстыкі, выдадзеных у міжваенны перыяд і сёння, успамінаў, таксама цікава паглядзець на тое, якое стаўленне да дысцыпліны часу было ў дыскурсе беларускіх камуністаў з КПЗБ, а таксама БСРГ. Элемент параўнання будзе вельмі карысны для ўдакладнення розніц і падабенстваў паміж рознымі беларускімі палітычнымі групамі і партыямі па пытанні развіцця заходнебеларускага грамадства ў міжваеннай Польшчы.

Неабходна таксама паглядзець на даследаванні сялянскіх супольнасцей, якія праводзіліся сацыёлагамі, этнолагамі, антраполагамі, географамі і палітолагамі ў Польшчы ў 1920-1930-я гады, у тым ліку манаграфічнага плана' ${ }^{6}$ Асабліва цікавымі з'яўляюцца матэрыялы конкурсаў аўтабіяграфій і ўспамінаў сялян і вясковых дзеячаў, якія праводзіліся ў 1930-я гады Інстытутам грамадскай гаспадаркі ў Варшаве, а таксама Дзяржаўным інстытутам культуры вёскі там жа ${ }^{7}$ Яны дазваляюць паглядзець на тое, як ідыёмы прагрэсу разумеліся і выкарыстоўваліся на лакальным узроўні на беларускіх землях міжваеннай Польшчы. Пры ўсёй дыстанцыі, якая аддзяляе нас ад міжваеннага перыяду, трэба прызнаць вартасць гэтых матэрыялаў.

Пры тым, што матэрыялы антрапалагічных даследаванняў 3'яўляюцца крыніцамі, разглядаць метадалагічна гэтую праблематыку мы будзем праз прызму прац па сімвалічнай антрапалогіі

${ }^{6}$ J. Obrębski, Studia etnosocjologiczne. T. I. Polesie, red. A. Engelking, Warszawa 2007; W. Staniewicz, Matujzy Bołondziszki, wieś powiatu lidzkiego, Warszawa 1923; S. Wysłouch, Świadomość narodowa ludności prawosławnej zamieszkujacej wschodnie i pótnocno-wschodnie powiaty Wileńszczyzny, Warszawa 1939.

${ }^{7}$ Pamiętniki emigrantów. T. I. Francja, Warszawa 1939; Wiejscy działacze spoteczni. T. I. Życiorysy wtościan, Warszawa 1937. 
i peasant studies (даследаванні сялянскіх грамадстваў). У прыватнасці, важныя для нас працы Мэры Дуглас, Віктара Цёрнера, Джэймса Скота і інш. ${ }^{8}$ Інтэрдысцыплінарная перспектыва дапаможа лепш раскрыць праблему часу і яго рацыянальнага выкарыстання.

Для лепшага разумення таго, чым быў падыход да грамадскага часу, нам неабходна супаставіць у дыскурсе друку пастулаты і тэзісы ідэалагічнай «тэорыі» 3 вопытам тых, каму быў адрасаваны друк БХД: беларускіх сялян. Нам трэба паглядзець, як яны апісвалі сваё стаўленне да катэгорый мінулага і будучыні, як апісвалі свой вопыт. Нарматыўны дыскурс часу павінен быць параўнаны 3 тым, якім чынам час пражываециа і ў якіх катэгорыях гэта апісваецца9 . Менавіта такі кантэкстуалізаваны антрапалагічны падыход дасць больш рэльефную карціну таго, чым з'яўляўся час на пэўным этапе для гэтага грамадства.

\section{Тыпалогіі грамадскага часу}

Час не з'яўляецца абстрактным і залежыць ад сацыяльнага рытму данага грамадства, паводле Эміля Дзюркгайма ${ }^{10}$. Эканамічныя адносіны ў грамадстве і ўзровень яго развіцця таксама адыгрываюць вызначальную ролю ў тым, як яно, яго палітычныя, эканамічныя і інтэлектуальныя эліты фармулююць і падтрымліваюць дыскурс адносна часу.

У чалавечых супольнасцях могуць суіснаваць шмат розных тыпаў часу. На гэта звярталі ўвагу спецыялісты ў галіне антрапалогіi, якія прысвячалі свае працы розным аспектам часу ў жыцці як заходніх, так і незаходніх грамадстваў. Пры гэтым існуюць як лінеарныя, так і цыклічныя мадэлі часу, якія ў тых або іншых формах

${ }^{8}$ M. Douglas, Implicit Meanings: Essays in Anthropology, Boston 1975; V. Turner, op. cit.; J. C. Scott, Domination and the Arts of Resistance: Hidden Transcripts, New Haven, London 1990.

${ }^{9}$ К. Гирц, Интерпретаиия культур, Москва 2004, с. 415-472.

${ }^{10}$ S. Kern, The Culture of Time and Space 1880-1918, Cambridge 1983, p. 19. 
могуць альбо суіснаваць, альбо быць у канфлікце ўнутры розных культур і рэлігій ${ }^{11}$. Пры гэтым не прырода, а культура вызначае характар календара, летазлічэння і вымярэння часу12.

Норберт Эліяс прапанаваў глядзець на час як частку «працэсу цывілізацыі», у выніку якога чалавечае грамадства набывае механізмы самадысцыпліны, стрымлівання паводзін членаў грамадства, якія функцыянуюць унутры іх саміх, праз складаную сетку сацыяльных сувязей ${ }^{13}$. Э. Дзюркгайм вылучаў «час прыватны» i «час увогуле» ${ }^{14}$. Апошні тып часу з'яўляецца грамадскім часам, рытмам, паводле якога жыве грамадства. Аднак сучаснае лінеарнае разуменне часу з'явілася менавіта ў іўдзейска-хрысціянскай традыцы. Ідэя сакральнага часу, мэтай руху якога з'яўляецца збаўленне, прыход збавіцеля-месіі, быў дакладна акрэслены ў хрысціянстве i іўдаізме. Аднак спатрэбілася Рэфармацыя, каб з'явілася ідэя часу як каштоўнага, у тым ліку і на ўзроўні штодзённага жыцця. Рэфармацыя і капіталістычная індустрыялізацыя прывялі да фарміравання дысцыпліны часу. Менавіта сярод пратэстантаў і ў пратэстанцкіх краінах паўночна-заходняй Еўропы (а таксама ў Паўночнай Амерыцы) гэтая дысцыпліна ўмацавалася ${ }^{15}$. Аднак гэтая ідэя, ужо ў адрыве ад свайго пратэстанцкага месца паходжання, атрымала глабальнае распаўсюджанне, хоць і не без лакальнага супраціўлення і спрэчак у выглядзе ўвядзення сусветнага стандартнага

${ }^{11}$ M. Bloch, The Past and the Present in the Present, "Man, New Series" 1977, Vol. 12, № 2, August, p. 278-292; К. Гирц, op. cit.; S. Hanson, Time and Revolution. Marxism and the Design of Soviet Institutions, Chapel Hill, London 1997; E. T. Hall, The Dance of Life: The Other Dimension of Time, Garden City, New York 1983; E. Zerubavel, Hidden Rythms. Schedules and Calendars in Social Life, Berkeley, Los Angeles 1985.

${ }^{12}$ E. Zerubavel, op. cit.

${ }^{13}$ N. Elias, The Civillizing Process, Oxford, Cambridge 2000; idem, Time. An Essay, Oxford, Cambridge 1992, p. 32-34, 146-148.

${ }^{14}$ S. Kern, op. cit., p. 19.

${ }^{15}$ S. Hanson, op. cit., p. 17-18. 
часу ${ }^{16}$. Нават незаходнія грамадствы мусілі суадносіць сябе 3 рытмам часу заходніх ${ }^{17}$.

Аднак зацвярджэнне гэтай новай сістэмы тэмпаральных каардынат і звязанага з ёй паняцця прадуктыўнасці нават ў заходніх грамадствах не адбывалася без канфліктаў. Мелі месца ўспышкі сацыяльных і палітычных канфліктаў. Сялянскія традыцыйныя ўзоры працы 3 іх недакладным вымярэннем часу згодна са штодзённым праходжаннем сонца па небе і яго сезоннымі адхіленнямі жорстка сутыкнуліся з вымярэннем часу паводле гадзінніка ${ }^{18}$.

Брытанскі гісторык-марксіст Эдвард Палмер Томпсан у 1970-х гадах указваў на палітычна канфліктную прыроду часу ў кантэксце замацавання новай капіталістычнай дысцыпліны часу на фабрыках. Мелі месца як адкрытыя сутыкненні, так і скрытыя тэхнікі супраціўлення ў тых асяроддзях індустрыяльных і аграрных рабочых, якія станавіліся аб'ектамі ууздзеяння новых дысцыплінарных практык ${ }^{19}$.

Але дысцыпліна часу і дыскурс звязаны з ёй у канкрэтных гістарычных абставінах неабавязкова адкідае ці ігнаруе множнасць мадэлей часу, акцэнтуючы толькі адну і перакрэсліваючы ўсе іншыя. Хутчэй, ён уключае пэўныя элементы некаторых з гэтых тыпаў часу. Нават дыяметральна розныя паміж сабой тыпы могуць сумяшчацца ў нарматыўным дыскурсе тэмпаральнай дысцыпліны, калі лінеарныя і нелінеарныя мадэлі часу выкарыстоўваюцца паралельна, служачы мэтам прыстасавання да выклікаў мадэрнасці.

${ }^{16}$ S. Kern, op. cit., p. 11-16; Ф. Б. Шенк, Универсальное время versus локальное время: железные дороги и споры о времяисчислении в России (1870-1910-е годы) [в:] Изобретение века. Проблемы и модели времени в России и Европе XIX столетия, под ред. Е. Вишленковой, Д. Сдвижкова, Москва 2013, с. 131-147.

${ }^{17}$ P. Duara, Historicizing National Identity, or Who Imagines What and When [in:] Becoming National. A Reader, eds. G. Eley, R. G. Suny, New York, Oxford 1996, p. 150-177; V. Tikhonov, Social Darwinism and Nationalism in Korea: the Beginnings (1880s-1910s). "Survival" as the Ideology of Korean Modernity, Leiden, Boston 2010.

${ }^{18}$ S. Hanson, op. cit., p. 17; J. Frykman, O. Löfgren, Narodziny czlowieka kulturalnego. Kształtowanie się klasy średniej w Szwecji XIX i XX w., Kęty 2007, s. 25-49.

${ }^{19}$ E. P. Thompson, Customs in Common, Harmondsworth 1993, p. 352-403. 
Абапіраючыся на спадчыну нямецкага сацыёлага Макса Вебера, амерыканскі даследчык Стывен Хэнсан сцвярджаў, што патрэбны змены ў ідэях грамадства, каб наступілі нейкія значныя тэхналагічныя і матэрыяльныя змены ${ }^{20}$. У абставінах сацыяльных крызісаў і жорсткага разрыву з практыкамі і ідэямі мінулага патрэбна надзвычайная мова, новыя ідэі, дыскурсы ${ }^{21}$. Друк беларускіх хрысціянскіх дэмакратаў актыўна распаўсюджваў такія новыя ідэі пра час, дысцыпліну часу, яе мэтазгоднасць у рамках праекта мадэрнасці як выратавання і руху ў эвалюцыйным кірунку. Парадаксальным чынам БХД, якая 3'явілася ў беларускім рымска-каталіцкім асяроддзі і сярод прыхільнікаў якой былі праваслаўныя беларусы, распаўсюджвала дысцыпліну часу, звязаную з пратэстантызмам, беларускіх прадстаўнікоў якога (метадыстаў, баптыстаў і інш.) хрысціянска-дэмакратычны друк кляйміў як «сектантаў» ${ }^{22}$, і капіталізмам, які лічыўся злом і адмаўляўся як у друку, так і ў праграмных дакументах хрысціянскіх дэмакратаў ${ }^{23}$.

Найбольш адпаведнай для разгляду перыяду сацыяльных і палітычных змен, на наш погляд, з'яўляецца тыпалогія грамадскага часу, прапанаваная палітолагам і сацыёлагам С. Хэнсанам. Яго тыпалогія ўяўляе сабой веберыянскую класіфікацыю грамадскага часу. Элементы тут адпавядаюць вылучаным М. Веберам тыпам правадырства. Гэта традыц̧ыйны час, які рэгіструецца

${ }^{20}$ S. Hanson, op. cit., p. 13.

${ }^{21}$ P. Bourdieu, Structures, Habitus, Power: Basis for a Theory of Symbolic Power [in:] Culture. Power. History. A Reader in Contemporary Social Theory, eds. N. B. Dirks, G. Eley, S. B. Ortner, Princeton, New Jersey 1994, p. 165-166; Л. Хант, Франиузская революиия: нулевой градус времени [в:] Изобретение века..., с. 52.

22 Sluchoŭski, Metadyskaja „sprawiadliwaść”, „Biełaruskaja Krynica” 1927, № 38, 16 wieraśnia, s. 4; Metodyzm u Zachodniaj Biełarusi i prychilnaść da jaho Ułłasawa, Łuckiewiča i Janki Stankiewiča, „Biełaruskaja Krynica” 1929, № 18, 12 traŭnia, s. 2; Sektanstwa šyrycca, „Biełaruskaja Krynica” 1931, № 26, 25 žniŭnia, s. 4; J. P., Sektanstwa ŭ biełaruskich masach i jaho pryčyny, „Biełaruskaja Krynica” 1932, № 31, 10 wieraśnia, s. 1-2; M-st, Sektanstwa - hrob narodu, „Biełaruskaja Krynica” 1932, № 37, 30 kastryčnika, s. 4.

${ }^{23}$ А. Вашкевіч, op. cit., c. 30, 32, 34. 
і вымяраецца пры адсутнасці абстрактнай тэмпаральнай сістэмы каардынат. Пераважае ў ім цыклічнасць, абумоўленая традыцыйнымі сельскагаспадарчымі заняткамі. Далей, гэта мадэрны, або $p a-$ цыянальны час, які рэгіструецца з дапамогай абстрактнай сістэмы каардынат незалежных ад канкрэтных падзей, заснаваны на пэўным комплексе неперсанальных правіл і дысцыпліне. Трэці, і апошні, тып - гэта харызматычны час, які грунтуецца на поглядзе, што звычайны час можа быць пераадолены ці перасягнуты тымі, хто прыняў харызматычны тып правадырства. 3 усёй інтэнсіўнасцю ён праяўляецца ў перыяды вострых сацыяльных крызісаў ${ }^{24}$. Гэтыя тры тыпы грамадскага часу дапамогуць нам вызначыць характар рыторыкі дысцыпліны часу ў друку БХД-БНА.

\section{Палітызацыя грамадскага часу}

Час звязаны з палітыкай не толькі праз стварэнне палітычных арганізацый, дзяржаўных структур ці нацыянальных сімвалаў. Час на ўзроўні практычнай дзейнасці і на ўзроўні дыскурсу знітаваны 3 вялікай колькасцю аспектаў жыцця данага грамадства. Ён не зводзіцца да календароў, гадзіннікаў, рытмаў, раскладаў і інш. Дысцыпліна часу хоць і мае непасрэдныя адносіны з гэтымі матэрыяльнымі і сімвалічнымі элементамі ${ }^{25}$, але існуе ў сувязі 3 іншымі сацыяльнымі і культурнымі аспектамі данага грамадства. Іх трэба ўлічваць пры вывучэнні палітычнага кантэксту з'яўлення дыскурсу дысцыпліны часу. 3 іншага боку, сацыяльнае канструяванне часу павінна разглядацца як палітычны працэс. Сацыяльны парадак данага грамадства прасякнуты пэўнай культурнай канструкцыяй часу. Календары, расклады і рытмы з'яўляюцца падставамі штодзённага жыцця, таму эліты і маніпулююць імі ${ }^{26}$.

${ }^{24}$ S. Hanson, op. cit., p. 1-21.

${ }^{25}$ N. Elias, Time..., p. 14-15, 29-30.

${ }^{26} \mathrm{~K}$. Verdery, What Was Socialism and What Comes Next?, Princeton, New Jersey 1996, p. 39, 35. 
У міжваенны час заходнебеларускае грамадства ў Польшчы, а ў першую чаргу вёска, перажывала бурлівы працэс палітызацыі ${ }^{27}$. Ён непасрэдна закрануў і праблематыку часу. На самым павярхоўным узроўні гэта датычыла праграм разнастайных партый і аб'яднанняў, якія ў 1920-я гг. актыўна дзейнічалі на вёсцы. Барацьба за ўплыў на вяскоўцаў вялася ў тым ліку і з перспектывы часу. Цяжкасці з аднаўленнем гаспадаркі пасля Першай сусветнай вайны маглі станавіцца крыніцай жадання як мага хутчэйшага выратавання ад пакут штодзённасці. Сяляне не маглі доўга чакаць. Выбары у Сенат і Сейм Польшчы, любыя змены ў палітычным жыцці, чуткі прымушалі спадзявацца на хуткія перамены, а не чакаць цэлыя гады ці дзесяцігоддзі ${ }^{28}$.

Палітызацыя датычыла, вядома ж, і вобразу будучыні, бо кожны палітычны рух стварае свой «вобраз будучыні». Гэта вядзе да барацьбы за яе палітычны гарызонт ${ }^{29}$. Гэтау ус сваю чаргу тэлеалагічна падпарадкоўвае ўсю дзейнасць прыхільнікаў данага палітычнага руху пэўнай мэце, кожны крок, кожная перамога і здабыванне прыхільнікаў адначасова набліжаюць надыход гэтай будучыні і паскараюць сам ход падзей, што стварае эфект паскарэння часу ў патрэбным палітычным кірунку, паскарае рух да палітычнага «тысячагадовага царства $»^{30}$. Калі беларускія хрысціянскія дэмакраты, прыхільнікі больш памяркоўных беларускіх палітычных груп («Цэнтрасаюз»), прыхільнікі партыі «Вызваленне» не абяцалі імгненнага збаўлення ад пакут цяжкай сацыяльнай, эканамічнай і палітычнай сітуацыі,

${ }^{27}$ С. Токць, Беларуская вёска ў эпоху зьменаў. Другая палова ХІХ - першая траціна XX сm., Мінск 2007, с. 149-164.

${ }_{28}$ Rusticanus, Z nastrojów wsi białoruskiej, „Przegląd Wileński” 1926, № 13, 18 lipca, s. 4-5; J. Januszewska-Jurkiewicz, Stosunki narodowościowe na Wileńszczyźnie w latach 1920-1939, Katowice 2011, s. 108.

${ }^{29}$ B. A. Porter, The Social Nation and its Futures: English Liberalism and Polish Nationalism in Late Nineteenth-Century Warsaw, "The American Historical Review" 1996, Vol. 101, № 5, December, p. 1470-1492.

${ }^{30}$ J. F. Rinehart, Revolution and the Millennium: China, Mexico, and Iran, Westport, Connecticut 1997. 
то іх больш радыкальныя канкурэнты з КПЗБ ці БСРГ зусім такога не выключалі ${ }^{31}$. Хуткі надыход будучыні і магчымасць пераадолець час указваюць на харызматычны тып грамадскага часу характэрны для гэтых рухаў.

Такім чынам, у міжваеннай Заходняй Беларусі пытанне часу стала звязвацца $з$ палітыкай і ідэалогіяй. Час разглядаўся як рэсурс, на яго сталі глядзець як на нешта, чым можна авалодаць пры выкананні пэўных умоў. Умовай такой было перш за ўсё прыняцце вызначанай палітычнай праграмы данага руху ці партыі. На ўзроўні ж дыскурсу друкаваных выданняў час стаў фактарам стварэння супольнасці. Менавіта да будаўніцтва маральнай палітычнай супольнасці, заснаванай на маральных прынцыпах, імкнуўся друк беларускіх хрысціянскіх дэмакратаў. Дыскурс дысцыпліны часу паводле вызначэння быў нарматыўны.

Прыватны час закранаўся нарматыўным дыскурсам часу ў той жа ступені, што і час увогуле, г. зн. грамадскі час у больш вузкім сэнсе. Нарматыўны дыскурс дысцыпліны часу закранаў як прыватную, так і публічную сферу. Пытанні палітыкі ў дыскурсе друку БХД разглядаліся як элементы публічнай сферы ${ }^{32}$, а пытанні часу таксама можна разглядаць у гэтым ключы. Але артыкуляцыя дысцыпліны часу ў друку БХД сігналізавала, што існавалі альтэрнатывы прапанаваным мадэлям, а таксама імпліцытна прызнаваліся супраціўленне і неразуменне, калі не поўнае адмаўленне іх у заходнебеларускім грамадстве.

Тое, што адбывалася з беларускімі друкаванымі календарамі, з'яўляецца важным сімптомам палітызацыі часу. Календары сталі прасторай палітызацыі. Адначасова яны мелі важнае сімвалічнае значэнне. Яны былі інструментам распаўсюджвання беларускай на-

${ }^{31}$ C. Токць, op. cit., c. 157, 163; W. Mędrzecki, KPZB i KPZU a wieś ukraińska i białoruska, niepublikowany referat, 2008.

32 А. Пагарэлы, Прэса і публічная сфера ў заходнебеларускай вёсиы ў 192030-я гады, «Беларускі гістарычны агляд» 2016, т. 23, сш. 1-2, снежань, с. 18-40. 
цыянальнай ідэнтычнасці ${ }^{33}$. Адбывалася своеасаблівая нацыяналізацыя часу, якая адкрывала дзверы і іншаму працэсу.

Тэндэнцыя да палітызацыі календароў вызначылася яшчэ напярэдадні Першай сусветнай вайны і падчас яе ${ }^{34}$. Палітызацыю менавіта календароў не абавязкова разглядаць толькі як нешта негатыўнае. Гэта быў у нечым непазбежны працэс. Скарэй, можна казаць пра празмерную ідэалагізацыю і перавагу палітычнай рыторыкі, публіцыстыкі ў змесце і непрыхаваныя формы індактрынацыі, як гэта магло быць у календарах для вёскі ў БССР 35 .

Сам каляндар мог і не займаць большасці аб’ёму выдання. У календарах магла друкавацца інфармацыя аб палітычных партыях і рухах, абмяркоўваліся палітычныя пытанні, давалася разнастайная інфармацыя сельскагаспадарчага, культурнага, медыцынскага плана ${ }^{36}$. Літаратурныя творы там змяшчаліся рэгулярна яшчэ ў часы «Нашай нівы» ${ }^{37}$. Календары не былі толькі крыніцай інфармацыі пра даты, сезонныя асаблівасці вясковай гаспадаркі ці рэлігійныя святы і юбілеі. Яны былі адлюстраваннем працэсаў сацыяльных і культурных змен, што адбываліся уу грамадстве. Тое, што яны сталі адлюстроўваць і палітычны расклад сіл у ім ці рэтрансліраваць пэўную ідэалогію, можна разглядаць таксама як крайнасць працэсаў палітычнай дыферэнцыяцыі і сацыялізацыі.

Перыядычны друк сам па сабе быў прыкметай і носьбітам палітызацыі часу, свайго роду календаром і хронікай падзей сучаснасці. Французскі пісьменнік Поль Кладэль пісаў, што «ранішнія

33 С. Цыпрыяновіч (Я. Найдзюк), Беларуская Друкарня імя Францішка Скарыны ў Вільні (1926-1940), London 1991, с. 12; Г. Сагановіч, Беларускі каляндар у гістарычнай асвеще у 1910-1939 г., «Беларускі гістарычны агляд» 2015, т. 22, сш. 1-2, снежань, с. 214.

${ }^{34}$ Biełaruski kalandar na 1914 hod, Wilnia 1914; Biełaruski kalandar na 1917 hod, Wilnia 1916.

${ }^{35}$ Г. Сагановіч, op. cit., c. 216.

36 Я. Багдановіч, На жыциёвым шлляху, Мінск 1992, с. 94-95; С. Цыпрыяновіч (Я. Найдзюк), op. cit., с. 11.

${ }^{37}$ Biełaruski kalandar. 1915 hod, Wilnia 1914, s. 32-48. 
газеты даюць нам пачуццё сучаснасці ў яе татальнасці» ${ }^{38}$. Рэгулярнасць перыядычнага друку была прыкметай упэўненасці ў надыходзе будучыні, пэўнай стабільнасці. 3 такой перспектывы, напрыклад, частыя канфіскацыі і закрыццё «Беларускай крыніцы» ў 1936-1937 гадах былі свайго роду разбурэннем такой рэгулярнасці, стабільнасці, пагрозай для адчування вясковымі чытачамі сучаснасці і страты «праекта будучыні».

\section{Час як абмежаваны рэсурс і яго рацыянальнае выкарыстанне}

Палітызацыя часу не азначала татальнага падпарадкавання ўсіх відаў дзейнасці грамадства пэўнай ідэалагеме. Тое, што палітычным і эканамічным пытанням адводзілася цэнтральнае месца, не азначала, што дыскурс быў напоўнены толькі абстрактнымі заклікамі. Гаворка ішла пра пытанні культуры, адукацыі (самаадукацыі) і сельскай гаспадаркі. Чытачы беларускіх хрысціянска-дэмакратычных перыядычных выданняў павінны былі засяродзіцца, планаваць і выкарыстоўваць свой час на акрэсленыя віды дзейнасці, што набліжалі б іх да рэалізацыі мэт БХД.

Як мы бачылі, фактар календара быў у гэтым сэнсе вельмі важны. Каляндар на рубяжы XIX-XX стагоддзяў працягваў дамінаваць у масавых уяўленнях аб грамадскім часе ${ }^{39}$. Аднак календары ў Заходняй Беларусі маглі адыгрываць свае традыцыйныя функцыі. Напрыклад, імёны ў вёсцы ў міжваенны перыяд маглі даваць паводле календара ${ }^{40}$.

Календары для вяскоуцаў маглі пазіцыянавацца як нейтральныя паводле назваў і змяшчалі ў іх слова «беларускі». Гэта нейтральнасць не павінна ўводзіць у зман, бо гэтыя календары выдаваліся

\footnotetext{
${ }^{38}$ S. Kern, op. cit., p. 70.

${ }^{39}$ Ibidem, p. 34.

${ }^{40}$ У новай айчьне, Беласток 2001, с. 136.
} 
рознымі беларускімі палітычнымі групамі і партыямі, якія змагаліся паміж сабой за сімпатыі вяскоўцаў. У якасці выдаўца выступалі розныя групоўкі, якія прасоўвалі свае палітыка-ідэалагічныя і рэлігійныя парадкі дня ${ }^{41}$. Календары набылі палітычнае значэнне яшчэ і дзякуючы таму, што польскія ўлады таксама па-свойму ўспрымалі ix «падрыўны», палітычны характар ${ }^{42}$. Пытанне календара i выкліканыя ім канфлікты з польскай адміністрацыяй маглі прыводзіць да яго канфіскацыі. Гэта было свайго роду замахам на нацыянальны час ${ }^{43}$.

Прывучэнне да змен, што беларускі хрысціянска-дэмакратычны друк выразна падкрэсліваў ${ }^{44}$, было неабходна для авалодання сітуацыяй, кантролю свайго жыцця і свайго часу. Календары маглі быць арыенцірам, компасам, які мог дапамагчы не згубіцца ў зменлівым свеце і прытрымлівацца агульных палітычных і эканамічных мэт.

Абвесткі аб календарах на наступны год даваліся ў хрысціянска-дэмакратычным друку рэгулярна. Рэклама календароў давалася як у канцы года, так і ў пачатку ${ }^{45}$. Давалася інфармацыя аб магчымасці набыць календары. Як правіла, гаворка ішла аб беларускіх віленскіх кнігарнях. Пры канцы 1936 года «Беларуская крыніца» змясціла рэкламу двух календароў: «Беларускага адрыўнога календара на 1937 год» (кірыліцай і лацінкай) і «Беларускага сялянскага календара на 1937 год». Пры набыцці календароў оптам абяцаліся скідкі ${ }^{46}$. «Хрысьціянская думка» рэкламавала «Беларускі адрыўны

${ }_{41}^{41}$ Беларускі каляндар на 1927 год, Вільня [б. г.]; Беларускі каляндар на 1932 год, Вільня [б. г.].

42 Я. Багдановіч, op. cit., с. 94.

${ }^{43}$ Kanfiskata biełar. kalendara, „Biełaruskaja Krynica” 1925, № 5, 25 kastryčnika, s. 5; Kanfiskata biełaruskaha kalendara, „Biełaruskaja Krynica” 1929, № 35, 6 śniežnia, s. 2.

${ }^{44}$ Ad. St-ič, $Z$ aposznich dzion, „Krynica” 1923, № 3, 31 sakawika, s. 2; Sumny, Zadańni našaj moladzi, „Krynica” 1925, № 20, 17 traŭnia, s. 4.

${ }^{45}$ „Chryścijanskaja Dumka” 1939, № 1, 2 studzienia, s. 8.

46 „Biełaruskaja Krynica” 1936, № 50, 6 śniežnia, s. 4; № 51, 13 śniežnia, s. 4; № 52, 20 śniežnia, s. 4 . 
календар на 1938 год» ${ }^{47}$, а ў «Шляху моладзі» беларускія кніжныя і адрыўныя календары служылі таксама мэтам рэкламы кнігарні «Надзея» ${ }^{48}$.

Для сялян былі свае крытэрыі. Календары апрача каталіцкіх і праваслаўных імён павінны былі змяшчаць у першую чаргу звесткі аб метэаралагічных умовах, важных для вясковых гаспадароў ${ }^{49}$. Барацьба за беларускі каляндар і яго частыя канфіскацыі з боку польскіх адміністрацыйных улад мелі рысы няроўнай рыначнай барацьбы і спроб пазбавіць канкурэнта яго часткі рынку. Гэта магло рабіцца 3 мэтай распаўсюджвання календароў на польскай мове, бо беларускія адрыўныя календары і календары-кніжкі маглі разыходзіцца, як сцвярджалася, тыражом некалькі дзясяткаў тысяч экзэмпляраў і прыносіць фінансавы прыбытак выдаўцам ${ }^{50}$. Сукупны тыраж беларускіх календароў, паводле аднаго з удзельнікаў беларускай выдавецкай справы ў міжваеннай Вільні, мог дасягаць нават і ста тысяч экзэмпляраў ${ }^{51}$.

Патрэба ў беларускіх календарах выразна выказвалася карэспандэнтамі хрысціянска-дэмакратычных выданняў. Былі просьбы з боку карэспандэнтаў аб календары на лацінцы замест кірыліцы, але рэдакцыя запэўнівала, што календары змяшчаюць усе каталіцкія імёны і святы ${ }^{52}$. Распаўсюджваліся беларускія календары на вёсцы праз розныя каналы. Сяляне маглі іх прывозіць з Вільні купляючы ў беларускіх кнігарнях, іх маглі раздаваць ці прадаваць сялянам беларускія нацыянальныя актывісты ${ }^{53}$. Вясковыя карэспандэнты

47 „Chryścijanskaja Dumka” 1937, № 22, 20 śniežnia, s. 8.

48 «Шлях Моладзі» 1938, № 26, 30 сьнежня, с. 8.

49 Я. Багдановіч, op. cit., с. 94.

${ }^{50}$ Ibidem, c. 94-95; С. Цыпрыяновіч (Я. Найдзюк), op. cit., с. 11-12.

${ }^{51}$ Я. Багдановіч, op. cit., с. 94

52 „Biełaruskaja Krynica” 1927, № 51, 16 śniežnia, s. 4.

${ }^{53}$ М. Танк, Лісткі календара [у:] М. Танк, Збор твораў у 4 m. Т. 4. Вершы, дзённікі, пераклады, Мінск 1967, с. 393; Ю. Пракаповіч, Жыциёвыя сиежкі [у:] Лёс аднаго пакалення (успаміны), Беласток 1996, с. 22; Я. Жамойцін, 3 перажытога [у:] Лёс аднаго..., с. 60. 
адзначалі важнасць арганізацыі продажу календароў. Аўтар ліста са Слонімшчыны, які падпісаўся як «Селянін», менавіта гэтую праблему вынес у загаловак свайго ліста (хаця рэдакцыя сама магла даваць назвы карэспандэнцыям $)^{54}$. У рэшце рэшт, у канцы 1930-х гадоў высветлілася, што продаж беларускіх календароў і кніг не патрабуе спецыяльнага дазволу з боку польскіх адміністрацыйных улад ${ }^{55}$.

Стварэнне палітычна актыўнай маральнай супольнасці і пераадоленне адсталасці, дыстанцыі ў развіцці былі ў перыядычным друку БХД-БНА ўзаемазвязанымі задачамі. Яны патрабавалі падпарадкавання беларускіх вяскоўцау своеасабліваму патэрналізму з боку інтэлектуалаў і палітыкаў БХД-БНА. Сяляне павінны былі пераняць рыторыку выданняў беларускіх хадэкаў і кіравацца тымі прынцыпамі і поглядамі, якія яны распаўсюджвалі. Пытанні дысцыпліны часу і рацыянальнага выкарыстання яго былі часткай гэтай рыторыкі і яны не абмяжоўваліся толькі падкрэсліваннем важнасці беларускіх календароў.

Неабходнасць задумацца аб часе, пачаць мысліць 3 пункту гледжання будучыні ${ }^{56}$ i перспектывы сталі яшчэ ў першай палове 1920-х гадоў прадметам абмеркавання на старонках «Крыніцы» яе аўтарамі. Спачатку гаворка ішла аб плённым выкарыстанні зімовага перыяду, калі гаспадарчыя працы засяроджваліся непасрэдна ў сялянскай хаце ${ }^{57}$. Сярод прапанаваных замест пасіўнага правядзення часу відаў дзейнасці, апрача чытання кніг і газет, былі размовы («бяседы») аб заснаванні пажарных каманд, пераходзе на хутары, кааперацыі, сельскай гаспадарцы, лепшых спосабах гаспадарання,

${ }^{54}$ Селянін, Трэба сарганізаващь прадажу беларускіх календароц̆, „Biełaruskaja Krynica” 1934, № 39, 29 kastryčnika, s. 4.

${ }_{55}$ Kalendary i knižki možna pradavać biez dazvołu, „Chryścijanskaja Dumka” 1939, № 8, 1 sakavika, s. 3.

${ }^{56}$ Sławianin, Našaje żyćcio, „Biełaruskaja Krynica” 1927, № 21, 20 traŭnia, s. 4.

${ }^{57}$ Što rabić zimoj, pierakład M. H., ,Krynica” 1924, № 5, 1 sakavika, s. 4-5; Matusewič, Jak prawieści zimowuju paru?, „Biełaruskaja Krynica” 1926, № 2, 18 studnia, s. 4. 
першых захадах па прадухіленні інфекцыйных хвароб. Згадваліся таксама канцэрты, зімовыя віды спорту. Тады ж з'явіліся матэрыялы, якія выразна падкрэслівалі як карыснае выкарыстанне часу на гаспадарчую дзейнасць і чытанне кніг ${ }^{58}$. Пытанне рацыянальнага выкарыстання часу стала прадметам публічнага абмеркавання, станавілася на парадку дня ў публічнай сферы.

Лепшае выкарыстанне часу на старонках хрысціянска-дэмакратычнага друку вызначалася як чытанне кніг, газет, удзел у дзейнасці культурных і палітычных арганізацый ${ }^{59}$. Сярод апошніх перавага, аднак, аддавалася тым з іх, якія былі або непасрэдна звязаны з БХД, або іх дзейнасць не супярэчыла пастулатам і прыярытэтам яе ідэалогіi ${ }^{60}$. Гэта агучвалася ў такіх пасажах: «...Трэба нам больш чытаць свае [вылучана аўтарам. - A. П.] газеты, кніжкі на тэмы гаспадарскія, арганізаваць свае гурткі прасветна-культурна-гаспадарскія, прыкладам, „Беларускі інстытут гаспадаркі і культуры”, арганізаваць кааператывы, касы, бібліятэкі, чытальні, ладзіць курсы і інш.». Тое ж, што не адпавядала такому выкарыстанню часу, вызначалася як яго «марнаванне» ${ }^{61}$. Менавіта распаўсюджванне нацыянальнай і класавай свядомасці сярод вяскоўцаў лічылася адпаведным выкарыстаннем часу ${ }^{62}$.

Дысцыпліна часу ў версіі БХД не прадугледжвала нейкага абавязковага для ўсіх беларусаў раскладу ці графіку працы накшталт працы нейкіх устаноў ці транспарту. Яна не мела татальнага характару, не была жорсткай у сэнсе нейкіх знешніх санкцый за

${ }^{58}$ H. Kłakoŭski, Nowy Pahost, Dzisienski paw., „Krynica” 1924, № 10, 29 krasawika, s. 5-6.

${ }^{59}$ Pranuk Lebiadzki, Čas da pracy bracca!, „Biełaruskaja Krynica” 1927, № 37, 22 kastryčnika, s. 6.

${ }^{60}$ J. P., Naša chwaroba i leki ad jaje, „Biełaruskaja Krynica” 1928, № 46, 12 kastryčnika, s. 1.

${ }^{61}$ Małady Dub, Dawoli čas marnawać, biaremsia za pracu!, „Biełaruskaja Krynica” 1928, № 35, 17 čerwienia, s. 4; Р., Не марнуйма дарма часу!, «Беларуская Крыніца» 1931, № 14, 23 красавіка, с. 4.

${ }^{62}$ „Biełaruskaja Krynica” 1927, № 44, 28 kastryčnika, s. 6. 
яе парушэнне. Гэта дысцыпліна таксама не была прывязана да гадзінніка. Калі казаць пра яе сувязь 3 нейкім інструментам адліку часу, то гэта хутчэй былі календары, бо патрэба ў календарах была значна большай сярод заходнебеларускіх вяскоўцаў, чым патрэба ў гадзінніках, якіх, зрэшты, на вёсцы было мала ${ }^{63}$.

Нават само паняцце «дысцыпліна» не азначала нейкага гвалтоўнага прымусу з боку хрысціянска-дэмакратычных актывістаў, зрэшты, у іх не было не толькі магчымасці, але і жадання ажыццяўляць сваю праграму гвалтоўным шляхам. Фактычна на індывідуальным узроўні пакідалася значная свабода ў тым, на што менавіта рацыянальна выкарыстаць свой час і калі канкрэтна гэта зрабіць. Пазней гэта знайшло сваё адлюстраванне і ў друку БХД. Пры ўсім загадным ладзе і імператыўнасці тону прысвечаных часу матэрыялаў і карэспандэнцый выданняў БХД, перш за ўсё акцэнтавалася менавіта патрэба і карысць, якую прынясе адпаведнае, адэкватнае, паводле версіі друку БХД, гістарычнаму моманту выкарыстанне часу.

Роздум аб праблематыцы часу не абмяжоўваўся толькі беларускімі выданнямі ці прэсай БХД. Аб ім задумваліся і ў міжваеннай Польшчы ў цэлым. Гэта таксама знаходзіла адлюстраванне ў польскім друку. Напрыклад, гродзенская газета „Straż nad Niemnem” змясціла знакамітую прыпісаную Бенджаміну Франкліну (17051790) максіму “Time is money” («Час - гэта грошы») у загаловак артыкула. У артыкуле адсутнасць звычкі ў жыхароў Гродна не спазняцца, рабіць усё ў свой час і прытрымлівацца графіка прыпісвалася спадчыне царскай Расіi, на якую ўскладалася адказнасць за такі стан рэчаў. Яна таксама характарызавалася як адсталая краіна ${ }^{64}$.

У лютым 1928 года ўжо карэспандэнт «Беларускай крыніцы» 3 Пружаншчыны пад псеўданімам Янка Гром заклікаў з эмацыянальным націскам: «...Не трацьце час, бо час - гэта грошы!» ${ }^{65}$.

${ }^{63}$ Skarha, Halilejskija paradki, „Biełaruskaja Krynica” 1927, № 5, 28 studnia, s. 3.

${ }^{64}$ Time is money, „Straż nad Niemnem” 1923, № 20, 14 maja, s. 5.

65 Janka Hrom, Dawoli spać!, „Biełaruskaja Krynica” 1928, № 9, 3 lutaha, s. 4. 
Франклінаўская формула стала выразна гучаць ужо і на беларускай мове. Аднак спачатку менавіта гаспадарчы аспект эканоміі часу, яго рацыянальнага выкарыстання выразна не гучаў.

Ашчаднасць адносна часу і ўменне планаваць сваю дзейнасць набывалі сэнс у сувязі са своеасаблівай тэмпаральнай (часавай) маральнай эканоміяй, якая не проста зводзілася да ашчаднасці, але яшчэ вызначала прыярытэт таго ці іншага віду дзейнасці альбо адносін да яго, прадметаў, з'яў культуры ў штодзённасці і г. д. Сама ж такая эканомія у рамках патэрналізму інтэлектуалаў і палітыкаў БХД-БНА з'яўляецца інструментам гегемоніі супольнасиі ${ }^{66}$. Апошняя заснавана на сімвалічным кантролі інтэлектуалаў і палітыкаў, якія выступаюць ад імя вёскі і вяскоўцаў, і надаюць адным формам культуры перавагу над другімі ці адкідаюць пэўныя праявы і элементы культуры як неадпаведныя сапраўднай прыродзе супольнасці, якую яны спрабуюць пабудаваць. Час тут выступаў у якасці абмежаванага дабра, абмежаванага рэсурсу ${ }^{67}$, які трэба было ашчаджаць, берагчы і выкарыстоўваць.

Павышэнне ўзроўню адукацыі было супрацьлеглым марнаванню часу на дробязі. Менавіта так выказаў гэта карэспандэнт «Беларускай крыніцы» 3 Пастаўшчыны. Картачныя гульні, якія адбываліся ў адной вясковай хаце і збіралі вельмі шмат удзельнікаў, маглі заканчвацца спрэчкамі, а нават і бойкамі. Падпіска на «Беларускую крыніцу», чытанне кніг на роднай мове і размовы аб «карысных справах» супрацьпастаўляліся такому падыходу ў правядзенні вольнага часу. Аўтар карэспандэнцыі згадвае смех як санкцыю ў адносінах да тых, хто неадпаведна паводзіць сябе і марнуе час ${ }^{68}$.

${ }^{66}$ F. E. Mallon, op. cit., p. 11; K. Stauter-Halsted, The Nation in the Village. The Genesis of Peasant National Identity in Austrian Poland 1848-1914, Ithaca, London 2001, p.185-186.

${ }^{67}$ G. M. Foster, Peasant Society and the Image of Limited Good, "American Anthropologist. New Series" 1965, Vol. 67, № 2, April, p. 293-315.

${ }^{68}$ Sielanin, Ci nia lepš wolny čas wykarystać dla praświety čym marnawać na puściačynu?, „Biełaruskaja Krynica” 1931, № 7, 20 lutaha, s. 4. 
Сувязь эканоміі часу з непасрэднымі эканамічнымі выгадамі таксама падкрэслівалася ў друку БХД, нягледзячы на негатыўнае стаўленне хрысціянскіх дэмакратаў да капіталістычнай эканомікі. 3 канца 1920-х гадоў з'яўляецца матыў ашчаднасці ў эканамічным кантэксце. Свята ашчаднасці, якое з'явілася ў 1924 годзе ў Італіі і адзначаецца 31 кастрычніка, было беларускім друкам запазычана ва ўкраінцаў ${ }^{69}$. Пачынаючы 31929 года ў хрысціянска-дэмакратычных выданнях амаль штогод змяшчаліся публікацыі прысвечаныя Дню ашчаднасці. Значэнне гэтага матыву павялічвалася не толькі ў сувязі з разгортваннем крызісу эканомікі, які асабліва балюча ўдарыў па сельскай гаспадарцы аграрных рэгіёнаў міжваеннай Польшчы. Як мы бачылі, узмацняусся гаспадарчы складальнік эканоміі часу. Гэта асабліва праявілася са з'яўленнем спецыяльнага кааператыўнага сельскагаспадарчага часопіса БХД «Самапомач» у 1932 годзе. Сялян заклікалі пакінуць традыцыйныя экстэнсіўныя формы гаспадаркі і прыняць інтэнсіўныя, перайсці да якасна іншай ацэнкі вынікаў працы праз прадуктыўнасць ${ }^{70}$. Ашчаднасць у адносінах да рэсурсаў, ашчаднасць у адносінах да часу, у тым ліку і вольнага ад працы, ставіла пытанне аб мэтазгоднасці расходавання грашовых сродкаў: «Ашчаднасць праяўляцца можа нават з вялікшым значэннем і ў умелым імі абароце... Вялікай ашчаднасцяй будзе такжа ўмелае выкарыстыванне вольнага часу». У тым жа артыкуле прапаноўвалася рабіць уклады ў банках, каб грашовыя сродкі выкарыстаць больш эфектыўна. Да таго ж самага заклікала змешчанае на форзацы «Беларускага сялянскага календара» на 1939 год паведамленне з заклікам не захоўваць грошы ў хаце ў сенніку, пад печкай, за абразом, пры сабе ці пазычаць іх людзям. Гэта ўсё прыводзіць да страт. Ашчадныя касы і банкі былі лепшым выхадам. Далей ішла адкрытая рэклама кас Стэфчыка, куды сяляне маглі прынесці

${ }^{69}$ Сьвята ашчаднасьйі, „Biełaruskaja Krynica” 1929, № 30, 26 кастрычніка, c. 2 .

${ }^{70}$ Паз., Ашчаджайма пашу, „Sатаротас̌” 1937, № 13, 13 жніўня, с. 3. 
грошы і атрымаць вялікую выгаду для сябе. Такім чынам, час павінен быў стаць крыніцай прыбыткаў. Антыкапіталістычная рыторыка саступала тут на карысць эканамічнай мэтазгоднасці і росту дабрабыту ${ }^{71}$.

У артыкуле ў часопісе «Самапомач», апублікаваным у канцы кастрычніка 1937 года ў сувязі з надыходам свята ашчаднасці, чытачам прапаноўвалася ацэнка таго, што вясковыя гаспадары губляюць, калі марнуюць час і не выкарыстоўваюць яго рацыянальна. Чытачам прапаноўвалася пераацаніць свае падыходы да часу і да вядзення гаспадаркі ў цэлым ${ }^{72}$.

Дысцыпліна часу магла быць скіравана супраць ляноты. Гэта было звязана ў тым ліку з традыцыйнымі ўяўленнямі аб тым, што для сялян (калі не для ўсіх, то прынамсі для часткі) характэрна марнатраўства, нерацыянальнасць. Для традыцыйных эліт, а таксама і для свяшчэннікаў былі характэрныя такія ўяўленні ${ }^{73}$. Таму чытачы «Беларускай крыніцы» папярэджваліся і ўшчуваліся за гультайства ${ }^{74}$.

Ашчаднасць магла мець характар заахвочвання аўтаркіі, як у выпадку, калі часопіс «Шлях моладзі» заклікаў сваіх чытачоў не купляць тавары ў крамах у крызісны перыяд. Набыццё тавараў у крамах часопіс прыраўноўваў да марнатраўства ${ }^{75}$. Час і тут быў тым, што можна было ашчаджаць, правільна выкарыстоўваць: «Ня маем мы грашэй ашчаджаць, то кіруймася ў сваіх выдатках прынамся так, каб яны толькі карысць нам прыносілі. I тут мусім

71 Z. В., Ci majem my što aščadžać??, «Шлях Моладзі» 1938, № 22, 25 кастрычніка, с. 4; Беларускі сялянскі календар на 1939 год, Вільня 1939.

${ }^{72}$ Kolki tracim marnujučy čas? (na Dzień Aščadnaści), «Самапомач» 1937, № 17, 25 кастрычніка, с. 2-3.

${ }^{73}$ O. Kolberg, Dzieła wszystkie. T. 52. Biatoruś-Polesie, Wrocław, Poznań 1968, s. 80; J. P. Himka, Galician Villagers and the Ukrainian National Movement in the Nineteenth Century, Houndmills 1988, p. 135.

${ }^{74}$ W. D-a, Hultajski paniadziełak, „Biełaruskaja Krynica” 1936, № 48, 29 listapada, s. 4.

${ }^{75}$ Я-к, Ашчаджайма!, «Шлях Моладзі» 1932, № 10, кастрычнік, с. 5-6. 
сабе адразу сказаць: - Прэч з гарэлкай і тытунём. Таксама не марнаваць часу, а выкарыстываць яго ў як найлепшы спосаб - трэба чытаць, вучыцца, усведамляцца і г. д» ${ }^{76}$. Такім чынам, можна казаць пра свайго роду аўтаркію часу ў дыскурсе друку хрысціянска-дэмакратычных выданняў.

Праблема рацыянальнага выкарыстання часу магла адносіцца да псіхалагічнага і забаўляльнага аспектаў. Не толькі арганізацыя беларускіх паказаў было з гэтым звязана. Гэта азначала не толькі карыснае, але і цікавае правядзенне доўгіх зімовых вечароў, што, зрэшты, адзначалася яшчэ ў 1920-я гады. Чытанне ўголас газет магло быць адным са спосабаў не толькі падзяліцца інфармацыяй, але і змагання з нудой у перыяд, калі светлавы дзень быў кароткі ${ }^{77}$.

Дыскурс хрысціянска-дэмакратычных выданняў меў уплыў не толькі непасрэдна на тых, хто прымаў ідэалогію БХД-БНА як адзіную дапушчальную для беларускага грамадства. Калі звярнуцца да дзённікаў міжваеннай эпохі, то можна заўважыць, што і прадстаўнікі іншых ідэалагічных плыней маглі выкарыстоўваць рыторыку рацыянальнага выкарыстання часу. Так было ў выпадку паэта, сябра КПЗБ Максіма Танка (Яугена Скурко), які рэгулярна чытаў хрысціянска-дэмакратычныя газеты і часопісы. Таму няма нічога дзіўнага, што ў канцы 1930-х гадоў ён вырашыў навучыцца больш правільна распараджацца часам, каб яго не губляць ${ }^{78}$.

Час усё больш прызнаваўся каштоўным і абмежаваным рэсурсам, якім трэба было ўмець правільна распарадзіцца. «Марнаванне» часу на гульні ў карты ці вечарыны $з$ алкаголем адразала чалавека ад супольнасці, бо ён не ўмеў правільна, паводле вызначаных прыярытэтаў выкарыстаць час. Важна было не толькі на індывідуальным, прыватным узроўні правільна распараджацца часам,

${ }^{76}$ J-k, 10-ty Mižnarodny Dzień Aščadnaści, «Шлях Моладзі» 1933, № 10, кастрычнік, с. 7.

${ }^{77}$ Hutarki dziadźki Haŭryły, „Biełaruskaja Krynica” 1933, № 7, 12 lutaha, s. 3.

${ }^{78}$ М. Танк, op. cit., c. 403, 417. 
але і на ўзроўні ўсяго беларускага народа. Адсутнасць адзінства i салідарнасці сярод беларусаў пагражала самому іх існаванню ${ }^{79}$. Авалоданне часам павінна было стаць надзённай задачай беларусаў, рацыянальны або мадэрны час замацоўваў свае пазіцыі ў дыскурсе як фактар стварэння маральнай супольнасці. Адзінства мэт, прыняцце агульных каштоўнасцей павінна было спрыяць стварэнню палітычна актыўнай супольнасці. Пры гэтым дзеянне на ўзроўні публічнай сферы было істотным, але быў важны і індывідуальны ўзровень асобных сяброў, якія мусілі самі прыняць ідэалогію БХД ${ }^{80}$. Гэта было сугучна з пратэстанцкай ідэяй аб хрысціянстве, якое мела трансфармацыйную сілу, што ўздзейнічала праз прыватную сферу ${ }^{81}$. Гэта быў калектыўны праект мадэрнасці сфармуляваны інтэлектуаламі і палітыкамі БХД. Тут быў важны прынцып актыўнага жыцця, або vita activa ${ }^{82}$.

Пры ўсёй рэдкасці і адначасовай другаснасці для часткі вяскоўцаў гадзіннікаў, у хрысціянска-дэмакратычных выданнях можна было сустрэць іх рэкламу ${ }^{83}$. Аднак часам гадзіннікі выступалі як прадмет бартэру ${ }^{84}$. Гадзіннік хоць і не выступаў так выразна ў якасці сімвала і інструмента як каляндар, але прысутнічаў на старонках друку. Напрыклад, магла давацца інфармацыя пра тое, што

${ }^{79}$ A. K., Nia nożam, dyk čaranami, „Biełaruskaja Krynica” 1928, № 43, 12 wieraśnia, s. 1; Этнаграфічная маса - рэгіёналізм - свабода адзінак, «Беларуская Крыніца» 1932, № 12, 20 сакавіка, с. 1.

${ }^{80}$ Zaściankowy Padpiečnik, ,Krynica” pramywaje wočy, „Krynica” 1925, № 13, 29 sakawika, s. 4.

${ }^{81}$ P. van Rooden, Nineteenth-Century Representations of Missionary Conversion and the Transformation of Western Christianity [in:] Conversion to Modernities. The Globalization of Christianity, eds. P. van der Veer, New York, London 1996, p. 66.

${ }^{82}$ M. Berman, All that is Solid Melts Into Air. The Experience of Modernity, New York 1988, p. 92.

${ }^{83}$ Raspradaža 500 hadzinnikaŭ, „Biełaruskaja Krynica” 1929, № 18, 12 traŭnia, s. 4.

${ }^{84}$ P. D., Za karowu - hadzinnik, „Biełaruskaja Krynica” 1927, № 36, 2 wieraśnia, s. 6. 
адбываецца па ўсёй Зямлі на працягу адной гадзіны ${ }^{85}$. Так беларускае грамадства сімвалічна параўноўвала сябе з глабальнымі сацыяльнымі і прыроднымі рытмамі, гэта рыхтавала глебу для культурных, эканамічных і грамадскіх адносін заснаваных не толькі на календары, але і на гадзінніку. Праўда, у міжваенны час, як можна меркаваць 3 матэрыялу аднаго 3 аўтараў «Беларускай крыніцы», гадзіннікі скарэй былі атрыбутам гарадскога жыцця. Беспрацоўныя гараджане, якіх накіроўвалі на працу ў вёску, адчувалі патрэбу даведацца, які час паводле гадзінніка, а вяскоўцы - не ${ }^{86}$.

Планаванне ўжо ў большым маштабе ў рамках усяго грамадства пачынала таксама набываць значэнне. Планаванне эканамічнай дзейнасці павінна было стаць сродкам змагання $з$ крызіснымі з'явамі ў эканоміцы і дапамагчы ў пераадоленні беспрацоўя ${ }^{87}$. А прынцып прадуктыўнасці станавіўся крытэрыем ацэнкі вынікаў дзейнасці не толькі ў сферы сельскай гаспадаркі, але і грамадскай і культурнай дзейнасці ${ }^{88}$.

Канцэпцыю часу БХД і звязаную з ёй дысцыпліну можна ахарактарызаваць як рацыянальныя або мадэрныя паводле веберыянскай класіфікацыі С. Хэнсана. Але гэта зусім не азначае, што пэўныя элементы іншых тыпаў з гэтай класіфікацыі адсутнічалі ў канцэпцы часу БХД. Ужо ў самой рыторыцы з заклікамі не марнаваць час, дзейнічаць сумесна для стварэння беларускіх структур у вёсцы можна ўбачыць элемент харызматычнасці. Сам друк БХД-БНА быў носьбітам пэўных харызматычных прыкмет, якія ў вачах некаторых яго чытачоў вылучалі яго ў параўнанні з іншымі выданнямі,

${ }^{85}$ Što robicca na ziamli ŭ praciahu 1 hadziny, «Шлях Моладзі» 1934, № 4, красавік, с. 25.

${ }^{86}$ Ул. К., 3 над Hарачы, „Biełaruskaja Krynica” 1935, № 36, 6 kastryčnika, s. 3-4.

87 Т. Л., Аб прычынах безпраиоўя $i$ эканамічным крызысе (да справы «nлянаваньня ў народнай гаспадариыл»), «Шлях Моладзі» 1937, № 7, ліпень, c. 6-8.

${ }^{88}$ J. Malecki, Za praduktyŭnuju pracu, «Шлях Моладзі» 1937, № 5, май, с. 1516. 
крыніцамі інфармацыі і ўлады ${ }^{89}$. Як гэта ні дзіўна, але каб выдаваць тыя ж календары, віленскай Беларускай друкарні імя Ф. Скарыны даводзілася працаваць і ўначы, што было адначасова і элементам капіталістычнай рацыянальнай максімізацыі вынікаў і харызматычнага пераадолення абмежаванняў часу ${ }^{90}$.

Увогуле, у міжваенны перыяд для назіральнікаў дысцыпліна часу, тэмп працы і яе якасць былі звязанымі паміж сабой катэгорыямі. Адзін з вясковых актывістаў, селянін з Брэсцкага павета, адзначаў, што самакіраванне гміны ў яго мясцовасці жадала, каб «у маланкавым савецка-амерыканскім тэмпе ператварыць гмінную вёску ў павятовы горад 3 двухпавярховымі будынкамі, пакідаючы жыхароў у адных толькі нагавіцах» ${ }^{91}$. Аўтар не ведаў, што такое харызматычны ці рацыянальны час, але разумеў характар дзеянняў, якія апісвае гэтае паняцце, а таксама цану, якую грамадства вымушана за гэта плаціць.

31928 года часопіс «Хрысціянская думка» падкрэсліваў значэнне рэлігійных дат. Гэта датычыла дзён, калі адбываліся фэсты ў гонар пэўных святых. Святы Божага Нараджэння і Вялікадня таксама адыгрывалі значную ролю. Рэлігійны каляндар, сакральнае разуменне часу суіснавала са свецкім і перапляталася з ім. Дысцыпліна часу і рацыянальная арганізацыя працоўнага дня былі звязаны з рэлігійным фактарам. У артыкуле ксяндза Віктара Шутовіча адзначалася, што дзень павінен быць арганізаваны так, каб гаспадару ставала сіл на працу ў наступны дзень. Дзень павінен быў пачынацца 3 малітвы. Поруч $з$ тэмпаральнай арганізацыяй павінна было быць прадумана пытанне падзелу абавязкаў у сям’і гаспадара. Аўтар закранае праблему падзелу працы паміж мужчынамі і жанчынамі менавіта ў вясковым кантэксце і разважае аб прыкладзе, які

${ }^{89}$ Zaściankowy Padpiečnik, op. cit., s. 4; A. W., Sekret adhadali, „Biełaruskaja Krynica" 1929, № 10, 8 sakawika, s. 4.

90 Я. Багдановіч, op. cit., c. 97.

${ }^{91}$ Wiejscy działacze..., s. 403. 
ведае 3 уласнага вопыту92. Традыцыйныя нехрысціянскія паводле паходжання святы аграрнага цыклу, такія як Купалле і Дажынкі, набывалі новы нацыянальны сэнс, хоць яны былі звязаны з традыцыйным, цыклічным разуменнем часу ${ }^{93}$.

Асаблівае месца займала дата 25 сакавіка - дзень абвяшчэння незалежнасці Беларускай Народнай Рэспублікі. Гэтай даце надавалася вялікае значэнне. Праграмнай палітычнай мэтай БХД была поўная незалежнасць Беларусі, таму кожны год хрысціянска-дэмакратычны друк прысвячаў матэрыялы гэтай лёсавызначальнай падзеі. Аднак варта адзначыць, што гэта дата была не толькі элементам гістарычнага мінулага. Яна фактычна была, як бы гэта парадаксальна не гучала, арыенцірам для будучыні, тым, што яшчэ павінна было адбыцца. Гэта дата вызначала для беларусаў будучыню, якая ўжо ў тыя часы была рэалізавана іншымі народамі «ўсходу Еўропы» ${ }^{94}$. Такім чынам, гэта дата апраўдвала ашчаднасць і дысцыпліну часу, эвалюцыйную канцэпцыю развіцця, якую прапаноўвала БХД. Зрэшты, у гістарычнай частцы заходнебеларускіх календароў свята 25 Сакавіка 3'явілася ўжо ў 1920-я гады ${ }^{95}$.

У канцы 1930-х гадоў тэма рацыянальнага выкарыстання часу набыла характар псіхалагічнай глыбіні. Адзначалася, што кожны можа выкарыстоўваць час для працы і адпачынку адпаведна са сваім характарам. Звярталася ўвага на тое, што выпрацоўка звычкі адыгрывае важную ролю пры гэтым. Гнуткасць чалавечых адносін у сэнсе выбару канкрэтнага часу, які можа быць найбольш прадук-

${ }^{92}$ Ks. W. Š., Jak wykarystać dzień, „Chryścijanskaja Dumka” 1937, № 3, 5 lutaha, s. 2.

${ }^{93}$ W. D-a, Biełaruskaje Kupalle, „Biełaruskaja Krynica” 1935, № 27, 30 čerwienia, s. 3; Весялуха, Дажынкі, „Biełaruskaja Krynica” 1934, № 36, 14 kastryčnika, s. 4; P. Tatarynowič, Światy Izydar Chliebarob, „Chryścijanskaja Dumka” 1929, № 3, 10 lutaha, s. 2-9.

${ }_{94}$ W. D-a, 25 sakawik - narodnaje świata Biełarusaŭ, „Biełaruskaja Krynica” 1935, № 14, 24 sakawika, s. 1.

${ }_{95}$ Г. Сагановіч, ор. cit., с. 220-221; Беларускі календар на 1929 год, Вільня 1928, с. 44; Беларускі календар на 1923 год, Вільня [1922], с. 27. 
тыўны для дзейнасці, не азначае, што не павінна быць планавання дня. Апошняе павінна мець месца незалежна ад таго, хочацца гэта чалавеку ці не. Такім чынам, дзеяннямі індывідуума павінна была кіраваць вышэйшая за штодзённыя моманты рацыянальнасць. Важна было «разумна кіраваць нашай штодзённай працай». Аўтар матэрыялу на гэту тэму разважаў аб рацыянальнасці звязанай са здароўем, з патрэбай працаваць удзень, а спаць уначы. Раніцу аўтар традыцыйна лічыць самым лепшым часам для прадуктыўнай працы. Ацэньвае ён і значэнне разумовай, інтэлектуальнай працы, а таксама сацыяльнае становішча чалавека і яго ўплыў на прадуктыўнасць працы ${ }^{96}$. Былі аднак і іншыя практыкі і дыскурсы, якія ўяўлялі канкурэнцыю для хрысціянска-дэмакратычнай мадэлі часу.

\section{«Рэпрэсіўны» і «чужы» час}

Харызматычны тып часу быў непрымальны, «чужы» для беларускага хрысціянска-дэмакратычнага руху. Менавіта да такога тыпу часу можна аднесці яго мадальнасць, якая выплывала $з$ ідэалогіi КПЗБ і з практык савецкага рэжыму. С. Хэнсан падкрэслівае, што харызматычны тып часу характэрны для ленінісцкіх рэжымаў увогуле. У рамках такой мадэлі час можна было паскорыць, пераадолець. Адмаўленне гэтага тыпу часу хадэцкімі выданнямі рабілася як адкрыта, праз непрыманне камуністычнай ідэалогіi, так і ўскосна, праз сцвярджэнне неабходнасці не паскараць развіццё беларускага грамадства, а ісці шляхам паэтапнага эвалюцыйнага развіцця ${ }^{97}$. Камуністаў мала цікавіла традыцыйная культура вяскоўцаў і яе патэнцыял для будавання супольнасці, таму Дажынкі або Купалле не адыгрывалі ў іх планах вялікай ролі. Зрэшты, культурныя

${ }^{96}$ W. D-a, Najlepšaja hadzina dnia, „Biełaruskaja Krynica” 1936, № 50, 6 śnieżnia, s. 4.

${ }^{97}$ Nacyjanalizm, jaho hranicy i značeńnie, „Biełaruskaja Krynica” 1933, № 9, 26 lutaha, s. 1; Radykalizm na vioscy i biełaruskaść, „Chryścijanskaja Dumka” 1939, № 8, 1 sakawika, s. 1 . 
аспекты ў іх дзейнасці мелі другараднае значэнне. Нігілізм у нацыянальным пытанні захоўваўся да II з'езда КПЗБ у 1935 годзе. Але і пасля яго істотных змен ці пералому не наступіла ${ }^{98}$.

Аналіз лістовак КПЗБ, а таксама камуністычнага дыскурсу ў цэлым дае ўяўленне аб тым, што камуністы разглядалі бег часу як паскораны, як такі, што імкнецца да хуткай рэвалюцыі, да хуткай гвалтоўнай змены сацыяльнага, культурнага і эканамічнага ладу, што прадстаўлялася ў якасці адзінага магчымага сцэнарыя развіцця грамадства. Як правіла, камуністычныя публікацыі выкарыстоўвалі вельмі шмат сказаў з заклікамі і клічнікамі. Яны стваралі эмацыянальнае напружанне, што магло, паводле тэкстаў камуністычных перыядычных выданняў і лістовак, быць знята толькі шляхам рэвалюцыі 99 . Камуністычны погляд на грамадскі час, яго харызматычны варыянт супярэчылі падыходу БХД-БНА, для якой хуткі надыход камуністычнай версіі «тысячагадовага царства» ўяўляў сабой фальшывы погляд на развіццё грамадства, які абапіраўся на памылковыя аксіёмы марксісцкай парадыгмы. У гэтым быў і матыў рэвалюцыйнага «паскарэння эвалюцыі», што было квінтэсэнцыяй бальшавіцкага падыходу да грамадскага часу ${ }^{100}$.

Савецкія эксперыменты з часам разглядаліся негатыўна. Даследчыкі ахарактарызавалі савецкую мадэль грамадскага часу як харызматычна-рацыянальную. Бальшавікі ўмешваліся ў рэлігійныя традыцыі вяскоўцаў у БССР, знішчалі іх. «Беларуская крыніца» прыводзіла прыклад таго, як час мог быць прасторай культурнага канфлікту на рэлігійнай глебе ў БССР. Паводле апублікаваных у выданні навін з Савецкай Беларусі, сяляне, якім камуністычнае кіраўніцтва загадала з’явіцца на сход а 10 гадзіне, замест гэтага

${ }^{98}$ A. Bergman, Sprawy białoruskie w II Rzeczypospolitej, Warszawa 1984, s. 92. Праўда, былі і пэўныя выключэнні з гэтага правіла, параўн.: W. H., Ab patrebach našaj wioski, „Narodny Zwon” 1926, № 1, 7 śniežnia, s. 5-7.

${ }^{99}$ W. Mędrzecki, op. cit.

${ }^{100}$ S. Hanson, op. cit., p. 12-13. 
пайшлі ў касцёл, а на сход прыйшлі толькі а другой гадзіне дня ${ }^{101}$. Пры гэтым увядзенне ў СССР пяцідзённага працоўнага тыдня, што было яркай праявай савецкай мадэлі харызматычна-рацыянальнага часу, не выклікала спачатку нейкіх адназначна негатыўных каментарыяў. Пазней, праўда, «Беларуская крыніца» асвятляла наступствы пераходу да пяцідзённага тыдня і звярнула ўвагу на яго неэфектыўнасць ${ }^{102}$.

Таксама не ўсе версіі рацыянальнага часу маглі здавальняць беларусаў, якія былі прыхільнікамі БХД-БНА, зрэшты, і тых, хто не падтрымліваў яе. Гаворка ідзе пра час выплаты падаткаў і запазычанасці, адбыванне павіннасцей і розных работ. Свята Канстытуцыі - 3 Мая - улады маглі, каб падмануць вяскоўцаў, інтэрпрэтаваць як касцельнае. Гэта маглі быць і захады з боку прапольскіх ксяндзоў ${ }^{103}$. Падаткі, якія трэба было сплачваць рэгулярна, маглі быць, асабліва ва ўмовах эканамічнага крызісу і дэфіцыту гатоўкі, значным цяжарам для заходнебеларускіх сялян. Секвестратары маглі патрабаваць нават продажу абразоў, каб спагнаць з сялян запазычанасць за нявыплачаныя падаткі. Гэта выклікала моцнае абурэнне ${ }^{104}$. Польская дзяржава таксама магла груба ўмешвацца ў працоўныя рытмы сялян праз забарону працаваць на палях у Свята Канстытуцы 3 мая. Такім чынам спрабавалі этатызаваць час сялянства, якое мела свой погляд на тое, як яго аптымальна выкарыстаць у сезон сяўбы ${ }^{105}$. Такі час можна было б назваць «рэпрэсіўным».

Таксама рэпрэсіўным быў час у адносінах да прыходу дзяцей вяскоўцаў у польскія школы на ўрокі. Польскія настаўнікі прызна-

101 Уплыў рэлігіi сярод беларускіх сялян у Б.С.С.Р., «Беларуская Крыніца» 1929, № 30, 26 кастрычніка, с. 2.

${ }^{102}$ Piacidniowy rabočy tydzień, „Biełaruskaja Krynica” 1929, № 31, 10 listapada, s. 4.

103 Świrski, Padatki i „,kaścielnaje” świata, „Biełaruskaja Krynica” 1926, № 17, 23 traŭnia, s. 6.

${ }^{104}$ Susied, Užo i abrazy na padatki, „Biełaruskaja Krynica” 1926, № 26, s. 6.

${ }^{105}$ Al. S., „Kanstytucyja 3 maja”, „Biełaruskaja Krynica” 1927, № 19, 6 traŭnia, s. 2-3; K. Verdery, op. cit., p. 39-58. 
чалі канкрэтны час пачатку заняткаў. Дэфіцыт гадзіннікаў у вёсцы, звязаны $з$ галечай, не дазваляў у некаторых выпадках дзецям сялян прыходзіць на заняткі своечасова. Гэта прыводзіла да штрафных санкцый ${ }^{106}$.

Наўрад ці трэба здзіўляцца таму, што менавіта вопыт ваенна-рэвалюцыйных падзей 1914-1921 гадоў таксама паўплываў на адносіны вяскоуццау да часу. Рэпрэсіўны аспект гэтага часу мог мець досыць нечаканыя наступствы для тых, хто трапіў пад яго ўздзеянне. Патрэба працаваць паводле графіка ці раскладу прамысловага прадпрыемства магла прымаць прымусовы характар. Знаходжанне ў германскім палоне магло быць крыніцай такога вопыту. Так здарылася $з$ выхадцам $з$ вёскі на Віленшчыне, якому давялося працаваць на сталеліцейным прадпрыемстве ў Германіi. Нават пра свае ўцёкі адтуль ён разважаў у катэгорыях планавання і выбару адпаведнага часу ${ }^{107}$. Такім чынам, навязаныя чужыя культурныя катэгорыі даводзілася засвойваць, бо ад гэтага залежала адаптацыя да новых умоў і выхад з цяжкай сітуацыі.

\section{Адносіны да часу ў міжваеннай Заходняй Беларусі}

Не будзе чымсьці дзіўным сцвердзіць, што, нягледзячы на намаганні інтэлектуалаў і палітыкаў $з$ кола БХД, адносіны да часу ў міжваеннай Заходняй Беларусі значна адрозніваліся ад тых, якія прапагандаваў хадэцкі друк. Вёска ўсё ж не была ўпісана ў рытмы індустрыяльнага капіталізму, заходнебеларускія землі не былі закрануты маштабнай урбанізацыяй, і таму ведаць, каторая канкрэтна гадзіна і колькі хвілін, з некаторымі выключэннямі, вяскоўцы не мелі патрэбы, а вось змены дзён і месяцаў іх цікавілі больш. Нельга сказаць, што надыход новых відаў камунікацыі і нясмелыя крокі мадэрнізацыі не закрануў практыкі вяскоўцаў па вымярэнні часу.

106 Skarha, op. cit., s. 3.

${ }^{107}$ Pamiętniki emigrantów..., s. 332-333. 
Напрыклад, курсіраванне цягнікоў магло быць арыенцірам для іх: «Яго [вёскі Курган. - А. П.] дрымоту парушалі штодня толькі два цягнікі: адзін ранішні, а восьмай гадзіне, у Вільню, а другі вячэрні, таксама а восьмай, у Варшаву. Абодва цягнікі для навакольных сялянаў і пастушкоў служылі паказальнікамі часу» ${ }^{108}$. Сяляне, асабліва старэйшага пакалення, увогуле маглі без карыстання календарамі і гадзіннікамі вызначаць даты пачатку тых ці іншых прац у гаспадарцы, змены ў рытмах прыроды, што выклікала здзіўленне назіральнікаў, якія самі ўжо карысталіся мадэрнай сістэмай тэмпаральных каардынат не паводле фаз Месяца: «Бацька мой заўсёды кажа, што пад трэцюю квадру і пад маладзік ніколі не трэба сеяць жыта. Праверу сёння, якая квадра, каб не пачынаць і мне сваёй сяўбы ў нешчаслівы час» ${ }^{109}$. Добрую характарыстыку таго, як ставіліся да часу прадстаўнікі старэйшага пакалення ў міжваенны перыяд, даў пісьменнік Аляксей Карпюк: «Час для бабак вымяраўся ад касьбы да жніва, ад жніва да пасеваў, хваробы, смерці знаёмых, хрэсьбін. Календарамі ці гадзіннікамі карыстацца яны не ўмелі» ${ }^{110}$.

У перыяд асабліва вострай галечы на вёсцы ў сялян проста не магло быць сродкаў на набыццё календароў, якія ў пачатку 1920-х гадоў былі рэдкай з'явай ${ }^{111}$. Матэрыяльны фактар уплываў на тое, ці жылі вяскоўцы «ў часе», ці сапраўды апыналіся «па-за» ім. Нават большы ў параўнанні з даваеннай эпохай кантакт з перыядычным друкам меў свае асаблівасці. Самі паняцці «штотыднёвая газета» ці «штомесячны часопіс» задавалі пэўны рэгулярны тэмпаральны рэжым, былі ўзорам дысцыпліны. Але беларускі і нават польскі друк трапляў на вёску спарадычна ${ }^{112}$.

У поглядах і дзейнасці сялян панавала не ашчаднасць у адносінах да часу, не стаўленне да яго як рэсурсу, але абыякавасць

\footnotetext{
108 Я. Жамойцін, op. cit., с. 63.

${ }^{109}$ М. Танк, op. cit., с. 257-258, 403.

110 А. Карпюк, Вершалінскі рай, Мінск 1974, с. 242.

${ }^{111}$ W. Staniewicz, op. cit., s. 121.

112 У новай айчьне, с. 242.
} 
і пасіўнасць. Гарызонт будучыні не перавышаў самай бліжэйшай часавай перспектывы. Паводле аднаго назіральніка «Беларускай крыніцы», сярод сялянства нестабільнасць ваенна-рэвалюцыйнага перыяду 1914-1921 гадоў стварыла адчуванне «нясталасці жыцця» i раўнадушнасці да самастойнай дзейнасці, разлічанай на далёкую перспектыву. Яны толькі чакалі ${ }^{113}$. Наўрад ці большасць беларускіх сялян мела гарызонт планавання на 50 год. Ён ва ўмовах натуральнай гаспадаркі быў значна вузейшы. Зрэшты, нельга сказаць, каб такі тэрмін моцна акцэнтаваўся ці нават падкрэсліваўся ў праграмных дакументах БХД, тым не менш, ён быў свайго роду прагнозам таго, які час можа спатрэбіцца на ажыццяўленне такой праграмы.

У 1920-я гады чаканне хуткіх перамен было рысай мыслення сялянства, якое хацела тэрмінова пазбыцца вынікаў разбурэння, голаду і галечы, якія прынесла Першая сусветная вайна. Гэтыя настроі праявіліся падчас выбарчай кампаніi 1922 года. Іх усплёск можна бачыць і ў перыяд пасля Майскага перавароту 1926 года, у выніку якога да ўлады прыйшоў маршал Юзаф Пілсудскі ${ }^{114}$. Гэтыя настроі нікуды не зніклі, а толькі уузмацніліся ў канцы 1930-х гадоў ${ }^{115}$.

У вёсках, якія былі пад моцным уплывам камуністычнай прапаганды, чаканне прымала формы нават поўнага культурнага і гаспадарчага квіетызму. Гаворка магла ісці не проста пра адсутнасць якіх-небудзь праяў жыцця грамадзянскай супольнасці. Чаканне выражалася ў тым, што сяляне проста пераставалі займацца нават сельскагаспадарчай дзейнасцю і чакалі прыходу саветаў. Само iснаванне польскай дзяржавы разглядалася якраз як «часовае» ${ }^{116}$.

113 Баранаўскі, Дэмаралізацьыя беларускай вёскі (ад нашага баранавіц̧кага карэспандэнта), „Biełaruskaja Krynica” 1935, № 6, 3 lutaha, s. 1.

114 J. Januszewska-Jurkiewicz, op. cit., s. 108; A. Bergman, op. cit., s. 94; Rusticanus, op. cit., s. 4-5; Sielanin, Staraja pieśnia, „Biełaruskaja Krynica” 1926, № 22, 11 lipnia, s. 6.

${ }^{115}$ S. Wysłouch, op. cit., s. 22, 24.

${ }^{116}$ Ibidem, s. 32. 
Апрача чакання праяўлялася яшчэ і настальгія па даваенным перыядзе, якая набыла мудрагелісты характар. Польскі антраполаг Юзаф Абрэмбскі ўказваў на ўяўленні аб «слабодзе» як на важныя для разумення погляду палешукоў на сучаснасць ${ }^{117}$. Гэта быў ідэалізаваны погляд на эпоху перад вайной, калі сяляне жылі больш заможна і бяспечна, які кантраставаў з перыядам змен, нестабільнасці, няпэўнасці і нясталасці ваеннай эпохі ${ }^{118}$. Настальгію па даваеннай эпосе як па часе, у якім было прасцей жыць 3 матэрыяльнага пункту гледжання, можна сустрэць нават у карэспандэнцыях у «Беларускую крыніцу» ${ }^{119}$.

Думкі аб хуткім паляпшэнні ўласнай сітуацыі, пасіўнае чаканне вельмі слаба спалучаюцца 3 эвалюцыйнай канцэпцыяй развіцця грамадства, рацыянальнай канцэпцыяй грамадскага часу і яго дысцыплінай, якія ўсё ж патрабавалі актыўнага жадання змен і мэтанакіраваных індывідуальных і калектыўных намаганняў. Вяскоўцы ў сваім чаканні вельмі своеасабліва ўспрынялі пасланне хрысціянска-дэмакратычных выданняў канца 1930-х гадоў - ашчаджаць час: яны не жадалі ўдзельнічаць у культурных і гаспадарчых арганізацыях - ні польскіх, ні беларускіх, матывуючы гэта ў тым ліку «марнаваннем часу і сродкаў» ${ }^{120}$. Сяляне, міма ўвагі якіх не прайшла рыторыка хрысціянска-дэмакратычнага друку, але не толькі яна, выкарыстоўвалі гэты матыў з тым, каб аднолькава дыстанцыравацца па магчымасці і ад польскай дзяржавы, і ад актывістаў былой КПЗБ, і ад больш цэнтрысцкіх сіл нацыянальнага руху.

${ }^{117}$ J. Obrębski, Studia etnosocjologiczne..., s. 546.

${ }^{118}$ Ibidem, s. 463-471.

119 Śloznawoki, Ni ŭzad, ni ŭpierad, „Biełaruskaja Krynica” 1926, № 23, 18 lipnia, s. 6 .

${ }^{120}$ S. Wysłouch, op. cit., s. 41-42, 81, 93; J. C. Scott, op. cit. 


\section{Вывады}

Канцэпцыя часу БХД была гнуткая, што суадносілася з яе большай увагай да культурнай спецыфікі беларускага грамадства, адмаўленнем рэвалюцыі, таталітарных і аўтарытарных падыходаў да палітыкі і эканомікі. Таму мадэль грамадскага часу БХД, калі прыняць веберыянскую класіфікацыю, спалучала ў сабе рацыянальны, або мадэрны і традыцыйны часы. Для больш радыкальнай камуністычнай плыні было характэрнае харызматычнае разуменне часу, што ў пэўнай ступені адрознівалася ад бальшавіцкай савецкай мадэлі ${ }^{121}$.

Прапанаваная беларускімі хрысціянска-дэмакратычнымі выданнямі дысцыпліна часу існавала ў прывязцы да праекта эвалюцыйнага развіцця заходнебеларускага грамадства, падкрэслівала важнасць інтэнсіўных метадаў вядзення сельскай гаспадаркі, развіцця сеткі культурных і эканамічных арганізацый. Час павінен быў ашчаджацца і рацыянальна выкарыстоўвацца як на ўзроўні асобных беларусаў, так і на калектыўным, групавым узроўні, закранаючы як сферу прыватнага, так і публічнага, утвараючы супольнасць, дзе час належаў мэтам будучыні, якая дыктавала мадэлі паводзін, звязаныя з часам. Дыскурс дысцыпліны часу пераплятаўся не толькі з эканамічнай і культурнай дзейнасцю, але быў звязаны з чытаннем беларускай перыёдыкі і літаратуры і інш., утвараючы свайго роду сінтэз усіх гэтых элементаў, знітаваных праектам пабудовы мадэрнага беларускага грамадства паводле прынцыпаў, якія БХД-БНА лічыла адпаведнымі для беларусаў. Гэты дыскурс, аднак, ва ўмовах адсутнасці значных мадэрнізацыйных і ўрбанізацыйных зрухаў, заставаўся рыторыкай, якая толькі стварала тое, што само па сабе было «індустрыялізацыйнымі» сацыяльнымі чаканнямі ${ }^{122}$, але не дзейнічала ў рэчышчы поўнамаштабных змен.

${ }^{121}$ S. Hanson, op. cit.

${ }^{122}$ A. Valantiejus, Early Lithuanian Nationalism: Sources of its Legitimate Meanings in an Environment of Shifting Boundaries, „Nations and Nationalism” 2002, Vol. 8, № 3, p. 327. 
Працягласць часу, якую палітычныя рухі дэкларатыўна і ацэначна прадстаўляюць для рэалізацыі сваіх праграм, можа, на нашу думку, кінуць святло на тое, ці яны больш выкарыстоўвалі рытарычнае маніпуляванне, ці больш стараліся пераканаць сваіх патэнцыяльных прыхільнікаў ${ }^{123}$. Камуністычны рух абяцаў нерэальна хуткае збаўленне ад пакут, а хрысціянска-дэмакратычны ўсё ж больш цвяроза бачыў, што для гэтага спатрэбіцца больш часу.

У дыскурсе дысцыпліны часу таксама можна ўбачыць «мяккую» форму каланізацыі штодзённасці з дапамогай дысцыпліны часу ${ }^{124}$. Каляндар, пры ўсёй абмежаванасці гэтага дыскурсу, заставаўся поспехам беларускіх хрысціянскіх дэмакратаў, увасабленнем такога мяккага ўмяшання ў штодзённасць з боку інтэлектуалаў і палітыкаў гэтага палітычнага кірунку. Каляндар не быў інструментам арыентацыі будучыні, ён быў элементам штодзённасці. Вяскоўцы самі не схільныя былі думаць аб будучыні, іх фактычна здавальняў сённяшні дзень. Аднак у міжваенны перыяд не толькі вяскоўцы былі ў разгубленасці адносна будучыні. Еўрапейцы ў выніку Першай сусветнай, або Вялікай вайны самі былі дэзарыентаваныя. Пачуццё будучыні было страчана, жыццё цяперашнім момантам дамінавала ў настроях ${ }^{125}$. Вакуум жа, які ўтварылі такія настроі, імкліва запаўнялі фашысцкія і камуністычныя рухі і рэжымы. Яны давалі вялікай колькасці людзей пачуццё пачатку новай эпохі, пачуццё будучыні і перспектывы ${ }^{126}$.

${ }^{123}$ R. Harre, Persuasion and Manipulation [in:] Discourse and Communication: New Approaches to the Analysis of Mass Media Discourse and Communication, ed. T. A. van Dijk, Berlin, New York 1985, p. 126-142.

${ }^{124}$ K. Verdery, The Production and Defense of "the Romanian Nation", 1900 to World War II [in:] Nationalist Ideology and the Production of National Culture, ed. R. C. Fox, Washington DC 1990, p. 81-111; Idem, National Ideology Under Socialism. Identity and Cultural Politics in Ceauşescu Romania, Berkeley, Los Angeles, Oxford 1991.

125 Л. Ф. Селин, Путешествие на край ночи, Харьков, Ростов-на-Дону 1999, c. 49; M. Eksteins, Rites of Spring. The Great War and the Birth of the Modern Age, Boston, New York 1989, p. 256.

${ }^{126}$ R. Griffin, Modernism and Fascism: The Sense of a Beginning under Mussolini and Hitler, Basingstoke 2007. 
У праблематыцы часу таксама ўвасабляецца сутыкненне культурных і палітычных парадыгм. Камуністычны кірунак 3 яго квазірэлігійнай верай у месіянскую ролю рэвалюцыйнага рабочага класа быў схільны пагарджаць штодзённасцю, якая была дробяззю ў планах татальнага пераўладкавання культуры і грамадства праз іх фактычнае разбурэнне. Фактычна камуністы не дыферэнцыравалі рэлігію і палітыку, якія гістарычна і так моцна паміж сабой знітаваны $^{127}$. Але менавіта беларускія хрысціянскія дэмакраты па-сапраўднаму глыбока і сур'ёзна разумелі сувязь рэлігіі і палітыкі, якія спрабавалі адасобіць адну ад другой. Таму яны вызнавалі больш адкрыты і больш нюансаваны падыход да сацыяльнай і культурнай рэчаіснасці Заходняй Беларусі, з якой мелі справу. Тэрмін у 50 год ${ }^{128}$, які польскія палітыкі, паводле ацэнкі беларускіх, лічылі дастатковым, каб беларусы зніклі як асобны этнас, быў выкарыстаны для пазітыўных мэт. Гэта быў тэрмін патрэбны для выратавання беларусаў праз знаходжанне імі свайго шляху ў мадэрнасць, праз пабудову сучаснага грамадства, праз павелічэнне матэрыяльнага дабрабыту і павышэнне культурнага і адукацыйнага ўзроўню вяскоўцаў. Аднак гэтыя «50 год» не сталі часткай свядомасці большасці жыхароў Заходняй Беларусі так, як гэта артыкулявалі дзеячы БХД. Зрэшты, як аказалася ў 1939 годзе, гэтага часу яны і не мелі.

\section{Літаратура}

A. K., Nia nożam, dyk čaranami, „Biełaruskaja Krynica” 1928, № 43, 12 wieraśnia.

A. W., Sekret adhadali, „Biełaruskaja Krynica” 1929, № 10, 8 sakawika.

${ }^{127}$ I. Strenski, Why Politics Can't Be Freed From Religion, Oxford, Cambridge 2010; M. Burleigh, Sacred Causes: the Clash of Religion and Politics, from the Great War to the War on Terror, New York, London 2006.

${ }^{128}$ Žuk, Kudy iści i za kim?, „Narodny Zwon” 1926, № 1, 7 śniežnia, s. 3-4; Kpblxy спозьненае прызнаньне, «Грамадзкі Голас» 1924, № 17, 28 жніўня, с. 1; Al. S., Ślady niawolnictwa, „Biełaruskaja Krynica” 1927, № 23, 3 čerwienia, s. 1; М. Танк, op. cit., c. 364-365. 
A-č, Duch času i biełarusy, „Krynica” 1918, № 2, 14 studnia.

Ad. St-ič, Z aposznich dzion, „Krynica” 1923, № 3, 31 sakawika.

Al. S., „Kanstytucyja 3 maja”, „Biełaruskaja Krynica” 1927, № 19, 6 traŭnia.

Al. S., Ślady niawolnictwa, „Biełaruskaja Krynica” 1927, № 23, 3 čerwienia.

Bergman A., Sprawy białoruskie w II Rzeczypospolitej, Warszawa 1984.

Berman M., All that is Solid Melts Into Air. The Experience of Modernity, New York 1988.

„Biełaruskaja Krynica” 1927, № 44, 28 kastryčnika; № 51, 16 śniežnia; 1936, № 50, 6 śniežnia; № 51, 13 śniežnia; № 52, 20 śniežnia; 1937, № 22, 20 śniežnia; 1939, № 1, 2 studzienia.

Biełaruski kalandar na 1914 hod, Wilnia 1914.

Biełaruski kalandar na 1917 hod, Wilnia 1916.

Biełaruski kalandar. 1915 hod, Wilnia 1914.

Bloch M., The Past and the Present in the Present, "Man, New Series" 1977, Vol. 12, № 2, August.

Bourdieu P., Structures, Habitus, Power: Basis for a Theory of Symbolic Power [in:] Culture. Power. History. A Reader in Contemporary Social Theory, eds. N. B. Dirks, G. Eley, S. B. Ortner, Princeton, New Jersey 1994.

Burleigh M., Sacred Causes: the Clash of Religion and Politics, from the Great War to the War on Terror, New York, London 2006.

„Chryścijanskaja Dumka” 1937, nr 22, 20 śniežnia.

Douglas M., Implicit Meanings: Essays in Anthropology, Boston 1975.

Duara P., Historicizing National Identity, or Who Imagines What and When [in:] Becoming National. A Reader, eds. G. Eley, R. G. Suny, New York, Oxford 1996.

Eksteins M., Rites of Spring. The Great War and the Birth of the Modern Age, Boston, New York 1989.

Elias N., The Civillizing Process, Oxford, Cambridge 2000.

Elias N., Time. An Essay, Oxford, Cambridge 1992.

Foster G. M., Peasant Society and the Image of Limited Good, "American Anthropologist. New Series” 1965, Vol. 67, № 2, April.

Frykman J., Löfgren O., Narodziny człowieka kulturalnego. Kształtowanie się klasy średniej w Szwecji XIX i XX w., Kęty 2007.

Griffin R., Modernism and Fascism: The Sense of a Beginning under Mussolini and Hitler, Basingstoke 2007.

Hall E. T., The Dance of Life: The Other Dimension of Time, Garden City, New York 1983. 
Hanson S., Time and Revolution. Marxism and the Design of Soviet Institutions, Chapel Hill, London 1997.

Harre R., Persuasion and Manipulation [in:] Discourse and Communication: New Approaches to the Analysis of Mass Media Discourse and Communication, ed. T. A. van Dijk, Berlin, New York 1985.

Himka J. P., Galician Villagers and the Ukrainian National Movement in the Nineteenth Century, Houndmills 1988.

Hutarki dziadźki Haŭryły, „Biełaruskaja Krynica” 1933, № 7, 12 lutaha.

J. P., Naša chwaroba i leki ad jaje, „Biełaruskaja Krynica” 1928, № 46, 12 kastryčnika.

J. P., Sektanstwa ŭ biełaruskich masach i jaho pryčyny, „Biełaruskaja Krynica” 1932, № 31, 10 wieraśnia.

Janka Hrom, Dawoli spać!, „Biełaruskaja Krynica” 1928, № 9, 3 lutaha.

Januszewska-Jurkiewicz J., Stosunki narodowościowe na Wileńszczyźnie w latach 1920-1939, Katowice 2011.

J-k, 10-ty Mižnarodny Dzień Aščadnaści, «Шлях Моладзі» 1933, № 10, кастрычнік.

Kalendary i knižki možna pradavać biez dazvotu, „Chryścijanskaja Dumka” 1939, № 8, 1 sakavika.

Kanfiskata biełar. kalendara, „Biełaruskaja Krynica” 1925, № 5, 25 kastryčnika.

Kanfiskata biełaruskaha kalendara, „Biełaruskaja Krynica” 1929, № 35, 6 śniežnia.

Kern S., The Culture of Time and Space 1880-1918, Cambridge 1983.

Kłakoŭski H., Nowy Pahost, Dzisienski paw., „Krynica” 1924, № 10, 29 krasawika.

Kolberg O., Dzieła wszystkie. T. 52. Białoruś-Polesie, Wrocław, Poznań 1968.

Kolki tracim marnujučy čas? (na Dzień Aščadnaści), «Самапомач» 1937, № 17, 25 кастрычніка.

Ks. W. Š., Jak wykarystać dzień, „Chryścijanskaja Dumka” 1937, № 3, 5 lutaha.

Małady Dub, Dawoli čas marnawać, biaremsia za pracu!, „Biełaruskaja Krynica” 1928, № 35, 17 čerwienia.

Malecki J., Za praduktyŭnuju pracu, «Шлях Моладзі» 1937, № 5, май.

Mallon F. E., Peasant and Nation. The Making of Postcolonial Mexico and Peru, Berkeley, Los Angeles, London 1995.

Matusewič, Jak prawieści zimowuju paru?, „Biełaruskaja Krynica” 1926, № 2, 18 studnia.

Mędrzecki W., KPZB i KPZU a wieś ukraińska i białoruska, niepublikowany referat, 2008. 
Metodyzm u Zachodniaj Biełarusi i prychilnaść da jaho Ǔłasawa, Euckiewiča i Janki Stankiewiča, „Biełaruskaja Krynica” 1929, № 18, 12 traŭnia.

Moroz M., , Krynica”. Ideologia i przywódcy białoruskiego katolicyzmu, Białystok 2001.

M-st, Sektanstwa - hrob narodu, „Biełaruskaja Krynica” 1932, № 37, 30 kastryčnika.

Nacyjanalizm, jaho hranicy i značeńnie, „Biełaruskaja Krynica” 1933, № 9, 26 lutaha.

Obrębski J., Studia etnosocjologiczne. T. I. Polesie, red. A. Engelking, Warszawa 2007.

P. D., Za karowu - hadzinnik, „Biełaruskaja Krynica” 1927, № 36, 2 wieraśnia.

Pamiętniki emigrantów. T. I. Francja, Warszawa 1939.

Piacidniowy rabočy tydzień, „Biełaruskaja Krynica” 1929, № 31, 10 listapada.

Porter B. A., The Social Nation and its Futures: English Liberalism and Polish Nationalism in Late Nineteenth-Century Warsaw, "The American Historical Review" 1996, Vol. 101, № 5, December.

Pranuk Lebiadzki, Čas da pracy bracca!, „Biełaruskaja Krynica” 1927, № 37, 22 kastryčnika.

Radykalizm na vioscy i biełaruskaść, „Chryścijanskaja Dumka” 1939, № 8, 1 sakawika.

Raspradaža 500 hadzinnikaŭ, „Biełaruskaja Krynica” 1929, № 18, 12 traŭnia.

Rinehart J. F., Revolution and the Millennium: China, Mexico, and Iran, Westport, Connecticut 1997.

Rusticanus, Z nastrojów wsi białoruskiej, „Przegląd Wileński” 1926, № 13, 18 lipca.

Scott J. C., Domination and the Arts of Resistance: Hidden Transcripts, New Haven, London 1990.

Sektanstwa šyrycca, „Biełaruskaja Krynica” 1931, № 26, 25 žniŭnia.

Sielanin, Ci nia lepš wolny čas wykarystać dla praświety čym marnawać na puściačynu?, „Biełaruskaja Krynica” 1931, № 7, 20 lutaha.

Sielanin, Staraja pieśnia, „Biełaruskaja Krynica” 1926, № 22, 11 lipnia.

Skarha, Halilejskija paradki, „Biełaruskaja Krynica” 1927, № 5, 28 studnia.

Sławianin, Našaje żyćcio, „Biełaruskaja Krynica” 1927, № 21, 20 traŭnia.

Śloznawoki, Ni ŭzad, ni üpierad, „Biełaruskaja Krynica” 1926, № 23, 18 lipnia.

Sluchoŭski, Metadyskaja ,,sprawiadliwaść”, „Biełaruskaja Krynica” 1927, № 38, 16 wieraśnia.

Staniewicz W., Matujzy Bołondziszki, wieś powiatu lidzkiego, Warszawa 1923.

Stauter-Halsted K., The Nation in the Village. The Genesis of Peasant National Identity in Austrian Poland 1848-1914, Ithaca, London 2001.

Što rabić zimoj, pierakład M. H., „Krynica” 1924, № 5, 1 sakawika. 
Što robicca na ziamli ŭ praciahu 1 hadziny, «Шлях Моладзі» 1934, № 4, красавік. Strenski I., Why Politics Can't Be Freed From Religion, Oxford, Cambridge 2010. Sumny, Zadańni našaj moladzi, „Krynica” 1925, № 20, 17 traŭnia.

Susied, Užo i abrazy na padatki, „Biełaruskaja Krynica” 1926, № 26.

Świrski, Padatki i ,kaścielnaje” świata, „Biełaruskaja Krynica” 1926, № 17, 23 traŭnia.

Tatarynowič P., Światy Izydar Chliebarob, „Chryścijanskaja Dumka” 1929, № 3, 10 lutaha.

Thompson E. P., Customs in Common, Harmondsworth 1993.

Tikhonov V., Social Darwinism and Nationalism in Korea: the Beginnings (1880s-1910s). "Survival" as the Ideology of Korean Modernity, Leiden, Boston 2010.

Time is money, „Straż nad Niemnem” 1923, № 20, 14 maja.

Turner V., Drams, Fields and Metaphors. Symbolic Action in Human Society, Ithaca, London 1974.

Valantiejus A., Early Lithuanian Nationalism: Sources of its Legitimate Meanings in an Environment of Shifting Boundaries, "Nations and Nationalism" 2002, Vol. 8, № 3.

Van Rooden P., Nineteenth-Century Representations of Missionary Conversion and the Transformation of Western Christianity [in:] Conversion to Modernities. The Globalization of Christianity, eds. P. van der Veer, New York, London 1996.

Verdery K., National Ideology Under Socialism. Identity and Cultural Politics in Ceauşescu Romania, Berkeley, Los Angeles, Oxford 1991.

Verdery K., The Production and Defense of "the Romanian Nation", 1900 to World War II [in:] Nationalist Ideology and the Production of National Culture, ed. R. C. Fox, Washington DC 1990.

Verdery K., What Was Socialism and What Comes Next?, Princeton, New Jersey 1996.

W. D-a, 25 sakawik - narodnaje świata Biełarusaŭ, „Biełaruskaja Krynica” 1935, № 14, 24 sakawika.

W. D-a, Biełaruskaje Kupalle, „Biełaruskaja Krynica” 1935, № 27, 30 čerwienia.

W. D-a, Hultajski paniadziełak, „Biełaruskaja Krynica” 1936, № 48, 29 listapada.

W. D-a, Najlepšaja hadzina dnia, „Biełaruskaja Krynica” 1936, № 50, 6 śniežnia.

W. H., Ab patrebach našaj wioski, „Narodny Zwon” 1926, № 1, 7 śniežnia.

Wiejscy działacze społeczni. T. I. Życiorysy wtościan, Warszawa 1937.

Wysłouch S., Świadomość narodowa ludności prawosławnej zamieszkującej wschodnie i pótnocno-wschodnie powiaty Wileńszczyzny, Warszawa 1939.

Z. В., Ci majem my što aščadžać?, «Шлях Моладзі» 1938, № 22, 25 кастрычніка. 
Zaściankowy Padpiečnik, „Krynica” pramywaje wočy, „Krynica” 1925, № 13, 29 sakawika.

Zerubavel E., Hidden Rythms. Schedules and Calendars in Social Life, Berkeley, Los Angeles 1985.

Žuk, Kudy iści i za kim?, „Narodny Zwon” 1926, № 1, 7 śniežnia.

Багдановіч Я., На жыциёвым шиляху, Мінск 1992.

Баранаўскі, Дэмаралізаџыля беларускай вёскі (ад намага баранавіџккага карэспандэнта), „Biełaruskaja Krynica” 1935, № 6, 3 lutaha.

Беларускі календар на 1923 год, Вільня [1922].

Беларускі календар на 1929 год, Вільня 1928.

Беларускі каляндар на 1927 год, Вільня [б. г.].

Беларускі каляндар на 1932 год, Вільня [б. г.].

Беларускі сялянскі календар на 1939 год, Вільня 1939.

Ван Геннеп А., Обряды перехода, Москва 2002.

Вашкевіч А., Эвалюиыя Беларускай Хрысиіянскай Дэмакратыі у святле яе палітычных праграм [у:] «Спадчына» 2006, № 1.

Весялуха, Дажыникі, „Biełaruskaja Krynica” 1934, № 36, 14 kastryčnika.

Гирц К., Интерпретация культур, Москва 2004.

Жамойцін Я., 3 перажытога [у:] Лёс аднаго пакалення (успаміны), Беласток 1996.

Карпюк А., Вершалінскі рай, Мінск 1974.

Крыху спозьненае прызнаньне, «Грамадзкі Голас» 1924, № 17, 28 жніўня.

Пагарэлы А., Прэса і публічная сфера у заходнебеларускай вёсиы у 1920-30-я гады, «Беларускі гістарычны агляд» 2016, т. 23, сш. 1-2, снежань.

Паз., Ашчаджайма пашу, „Sатаротас̌” 1937, № 13, 13 жніўня.

Пракаповіч Ю., Жыциёвыя сцежкі [у:] Лёс аднаго пакалення (успаміны), Беласток 1996.

Р., Не марнуйма дарма часу!, «Беларуская Крыніца» 1931, № 14, 23 красавіка.

Сагановіч Г., Беларускі каляндар у гістарычнай асвеце у 1910-1939 г., «Беларускі гістарычны агляд» 2015, т. 22, сш. 1-2, снежань.

Селин Л. Ф., Путешествие на край ночи, Харьков, Ростов-на-Дону 1999.

Селянін, Трэба сарганізаваць прадажу беларускіх календароў, „Biełaruskaja Krynica" 1934, № 39, 29 kastryčnika.

Сьвята ашчаднасьиі, „Biełaruskaja Krynica” 1929, № 30, 26 кастрычніка.

Т. Л., Аб прычынах безпрацоўя і эканамічным крызысе (да справы «плянаваньня у народнай гаспадариыл)), «Шлях Моладзі» 1937, № 7, ліпень. 
Танк М., Лісткі календара [у:] М. Танк, Збор творай у 4 m. Т. 4. Bepшы, дзённікі, пераклады, Мінск 1967.

Токць С., Беларуская вёска у эпоху зьменаў. Другая палова XIX - першая траціна XX cm., Мінск 2007.

У новай айчыне, Беласток 2001.

Ул. К., 3 над Нарачbl, „Biełaruskaja Krynica” 1935, № 36, 6 kastryčnika.

Уплыў рэлісіі сярод беларускіх сялян у Б.С.С.Р., «Беларуская Крыніца» 1929, № 30, 26 кастрычніка.

Хант Л., Франиузская револючия: нулевой градус времени [в:] Изобретение века. Проблемы и модели времени в России и Европе ХІХ столетия, под ред. Е. Вишленковой, Д. Сдвижкова, Москва 2013.

Цыпрыяновіч С. (Найдзюк Я.), Беларуская Друкарня імя Францішка Скарыны у Вільні (1926-1940), London 1991.

Шенк Ф. Б., Универсальное время versus локальное время: железные дороги и споры о времяисчислении в России (1870-1910-е годы) [в:] Изобретение века. Проблемь и модели времени в России и Европе ХІХ столетия, под ред. Е. Вишленковой, Д. Сдвижкова, Москва 2013.

«Шлях Моладзі» 1938, № 26, 30 сьнежня.

Этнаграфічная маса - рэгіёналізм - свабода адзінак, «Беларуская Крыніца» 1932, № 12, 20 сакавіка.

Я-к, Ашчаджайма!, «Шлях Моладзі» 1932, № 10, кастрычнік.

\section{The problem of the time management in the BCD-BPU press discurses in the inter-war period}

The article is an attempt to study the problem of time discipline in the periodical press discourse of interwar Belarusian Christian Democracy. This discourse was an important element in shaping of an image of moral community comprising politically, socially and economically active Belarusians. However, not only political but also sociocultural factors to a large extent determined that the effect of this discourse on Belarusian village was rather limited. The article proposes a typology of social time which characterizes the attitudes toward time of Belarusian Christian Democracy and other political movements in West Belarus.

Kyewords: social time, press, West Belarus, interwar years, Belarusian Christian Democracy 